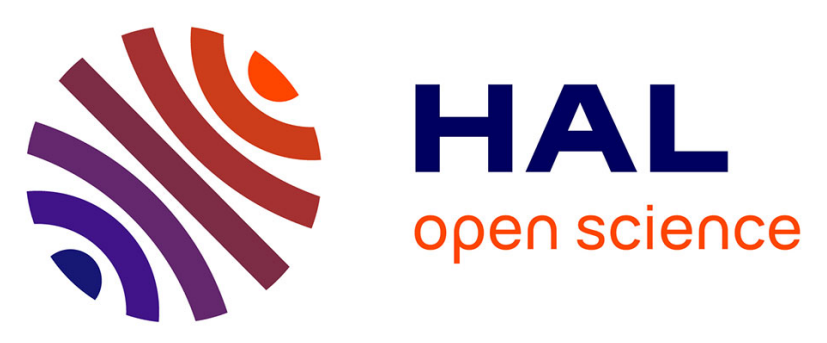

\title{
The Mid-Cenomanian Event in shallow marine environments: Influence on carbonate producers and depositional sequences (northern Aquitaine Basin, France)
}

Simon Andrieu, Benjamin Brigaud, Thomas Rabourg, Aurélie Noret

\section{To cite this version:}

Simon Andrieu, Benjamin Brigaud, Thomas Rabourg, Aurélie Noret. The Mid-Cenomanian Event in shallow marine environments: Influence on carbonate producers and depositional sequences (northern Aquitaine Basin, France). Cretaceous Research, 2015, 56, pp.587-607. 10.1016/j.cretres.2015.06.018 . hal-02541819

\section{HAL Id: hal-02541819 https: / hal-brgm.archives-ouvertes.fr/hal-02541819}

Submitted on 14 Apr 2020

HAL is a multi-disciplinary open access archive for the deposit and dissemination of scientific research documents, whether they are published or not. The documents may come from teaching and research institutions in France or abroad, or from public or private research centers.
L'archive ouverte pluridisciplinaire HAL, est destinée au dépôt et à la diffusion de documents scientifiques de niveau recherche, publiés ou non, émanant des établissements d'enseignement et de recherche français ou étrangers, des laboratoires publics ou privés. 


\section{The Mid-Cenomanian Event in shallow marine environments: Influence on carbonate producers and depositional sequences...}

Article in Cretaceous Research · July 2015

DOI: $10.1016 /$ j.cretres.2015.06.018

\section{CITATIONS}

4

4 authors, including:

\section{Simon Andrieu}

French Geological Survey

4 PUBLICATIONS 7 CITATIONS

SEE PROFILE

\section{Aurelie Noret}

Université Paris-Sud 11

27 PUBLICATIONS 103 CITATIONS

SEE PROFILE
READS

171

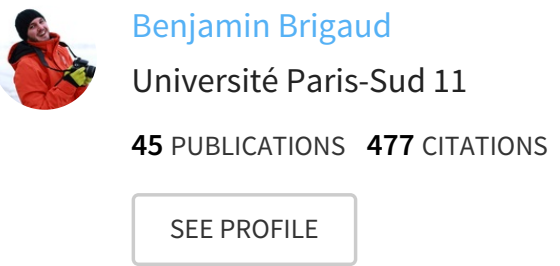

Some of the authors of this publication are also working on these related projects: 


\title{
The Mid-Cenomanian Event in shallow marine environments: Influence on carbonate producers and depositional sequences (northern Aquitaine Basin, France)
}

\author{
Simon Andrieu* ${ }^{*}$ Benjamin Brigaud, Thomas Rabourg, Aurélie Noret \\ Université Paris-Sud, UMR-CNRS 8148, Géosciences Paris-Sud, Bât. 504, 91405 Orsay Cedex, France
}

\section{A R T I C L E I N F O}

\section{Article history:}

Received 19 February 2015

Received in revised form 12 May 2015

Accepted in revised form 28 June 2015

Available online $\mathrm{xxx}$

\section{Keywords:}

Mid-Cenomanian Event

Aquitaine Basin

Carbonate

Carbon isotopes

Sequence stratigraphy

Facies

\begin{abstract}
A B S T R A C T
The Mid-Cenomanian Event was a positive carbon-isotope $\left(\delta^{13} \mathrm{C}\right)$ excursion recorded in hemipelagic basins of the western Tethyan Sea, North to Tropical Atlantic Ocean, and Japan. It is thought of as a prelude to the Oceanic Anoxic Event 2. However, the Mid-Cenomanian Event has never been studied in detail in shallow marine platform deposits and it is not known how it relates to carbonate production and stratigraphic geometry. To better understand how this carbon cycle disruption influenced the neritic biological communities in shallow carbonates during the Cenomanian, a facies, geochemical, diagenetic, and sequence stratigraphic study of the northern Aquitaine platform has been conducted. Seventy-six $\delta^{13} \mathrm{C}$ and $\delta^{18} \mathrm{O}$ measurements have been made on micrite, rudists, and diagenetic cements. Fifteen sedimentary facies have been arranged into four depositional environments. Three third-order sequences $\left(C_{B}, C_{C}, C_{D}\right)$ are defined from late early Cenomanian to early late Cenomanian and are well correlated with eustatic cycles in European basins. Two peaks of the Mid-Cenomanian Event (MCE1a, $+1.2 \%$, and MCE1b, $+1.7 \%$ ) have been identified for the first time in shallow marine carbonates. Analysis of diagenetic blocky calcite cements suggests that diagenesis did not affect the $\delta^{13} \mathrm{C}$ of micrite, which can be discussed in terms of the initial signal. The Mid-Cenomanian Event was synchronous with a turnover in neritic carbonate producers marking a transition from photozoan to heterozoan facies. This facies change resulted from the establishment of mesotrophic to eutrophic conditions at the early/midCenomanian transition, reflecting a clear connection between the Mid-Cenomanian Event and neritic biological communities. Depositional geometry and carbonate production varied with $\delta^{13} \mathrm{C}$ during the Mid-Cenomanian Event on the Aquitaine platform. When $\delta^{13} \mathrm{C}$ values were between $2.5 \%$ and $3 \%$, the geometry was a flat platform with a high carbonate sedimentation rate leading to the formation of sandbars and rudist bioherms (Accommodation/Sedimentation ratio less than $1, A / S<1$ ). When the $\delta^{13} C$ value exceeded $3 \%$, a carbonate demise occurred and clays and marls were deposited in the lower offshore environment $(\mathrm{A} / \mathrm{S}>>1)$. The general carbonate demise affecting the northern Aquitaine platform during the mid-Cenomanian can be explained by both a eustatic sea-level rise and the establishment of eutrophic conditions. The coincidence of the Mid-Cenomanian Event with both (1) the occurrence of mesotrophic to eutrophic conditions marked by carbonate producer turnover from photozoan to heterozoan facies and (2) the transgressive cycles, suggests that eustatic sea-level rise leading to high trophic conditions could explain this positive $\delta^{13} \mathrm{C}$ excursion in the Atlantic and western Tethyan domain. During the mid-Cenomanian, carbon cycle perturbations largely controlled the neritic biological communities on shallow carbonate platforms in a part of the western Tethyan domain.
\end{abstract}

() 2015 Elsevier Ltd. All rights reserved.

\footnotetext{
* Corresponding author.

E-mail address: simon.andrieu@u-psud.fr (S. Andrieu).
}

\section{Introduction}

The Late Cretaceous is thought to have experienced the highest sea levels of Phanerozoic times, peaking during the Cenomanian-Turonian ages (Haq et al., 1987; Miller et al., 2005; Haq, 2014). These high sea levels combined with high temperatures 
(Huber et al., 2002; Gustafsson et al., 2003; Forster et al., 2007) were very favorable to the development of carbonate platforms in Cenomanian intracratonic basins (Floquet, 1998; Pomar et al., 2005; Smith et al., 2006; Gertsch et al., 2008; El-Sabbagh et al., 2011). There are still uncertainties about the factors controlling the formation and evolution of carbonate ramps and platforms, especially in stable areas. These complex sedimentary systems are influenced by environmental changes (climate, sea level, trophic conditions) which can modify their geometry, depositional profile, and the relative abundance of the main carbonate producers (Frijia et al., 2015). In the present-day context of human-induced environmental upset, it is important to understand how tropical marine ecosystems react to such changes. Past carbonate platforms preserve a detailed record of how these particular environments are affected by sea-level changes and climatic and oceanographic conditions.

Perturbations of the global carbon cycle induce excursions in the carbon-isotope record of marine carbonates and organic matter. The Mid-Cenomanian Event (MCE1) was a carbon-isotope $\left(\delta^{13} \mathrm{C}\right)$ excursion characterized by two positive peaks: MCE1a (about $+0.5 \% 0$ ) and MCE1b (about $+1 \% 0$ ). MCE1 was recorded in marine carbonates in the eastern North Atlantic (England and northern France: Jenkyns et al., 1994; Paul et al., 1994; Mitchell et al., 1996; Jarvis et al., 2001, 2006; southeastern France: Giraud et al., 2013; Reboulet et al., 2013; Spain: Rodriguez-Lazaro et al., 1998; Stoll and Schrag, 2000; northern Germany: Mitchell et al., 1996; Wilmsen, 2007; Ando et al., 2009), western Mediterranean (Italy: Stoll and Schrag, 2000) and western interior Basin (Gale et al., 2008a,b), in marine organic carbon in the tropical Atlantic (Friedrich et al., 2009) and Morocco (Gertsch et al., 2010), and in terrestrial organic matter in Japan (Uramoto et al., 2007). MCE1 is characterized by the occurrence of black shales in ODP Leg 207 only (tropical Atlantic Ocean, Demerara Rise; Friedrich et al., 2009; Hardas et al., 2012). It is thought to have been a prelude to Oceanic Anoxic Event 2 (OAE2) at the Cenomanian/Turonian boundary (Coccioni and Galeotti, 2003).

All the studies of MCE1 have been carried out on basins or hemipelagic deep marine environments but none on shallow carbonate platforms. The effect of MCE1 on neritic biological communities is very poorly constrained. A first difficulty in obtaining a geochemical correlation between pelagic and neritic domains during the Cretaceous is often the low biostratigraphic constraint resolution in neritic carbonate sediments (Frijia et al., 2015). A second obstacle to defining a reliable geochemical record for neritic platforms is that diagenetic processes may modify the initial geochemical signal (Swart and Eberli, 2006).

Several stratigraphic studies of the Aquitaine platform are available for the Cretaceous as a whole (Platel, 1998; Biteau et al., 2006; Lasseur et al., 2008) and some studies focus on the biostratigraphy and lithostratigraphy of Cenomanian limestones (Moreau and Platel, 1982; Moreau, 1993, 1996). In this paper, we combine carbon and oxygen isotope analyses, sequence stratigraphy, diagenetic control, and facies study for the Cenomanian limestones of the northern Aquitaine Basin. These data are used (1) to compare the $\delta^{13} \mathrm{C}$ values recorded in the carbonates of the shallow Aquitaine platform and in the North Atlantic/western Tethys basins, and then (2) to investigate the potential connection between $\delta^{13} \mathrm{C}$ excursions and carbonate production or geometry turnovers in shallow environments.

In detail, a facies description and classification is proposed from which to define depositional environments. High-resolution correlations have been made to constrain the stratigraphic geometry. Measurements of $\delta^{13} \mathrm{C}$ are compared with facies, carbonate production, and sequence stratigraphy so as to better constrain the connection between carbon cycle disturbances and neritic carbonate producers.

\section{Geological setting}

The Aquitaine Basin is an intracontinental basin in southwestern France, in which a Hercynian crystalline basement is overlain by Triassic to Quaternary rocks (Biteau et al., 2006). The study area lies in the northern part of the Aquitaine Basin, $20 \mathrm{~km}$ west of Angoulême (Fig. 1). It extends for $5 \mathrm{~km}$ from east to west and $3 \mathrm{~km}$ from north to south. During the Late Cretaceous, the Aquitaine Basin formed a shallow epicontinental sea, at subtropical latitudes $\left(30^{\circ} \mathrm{N}\right)$, bordered to the east by the Massif Central, to the north by the Armorican Massif, and to the south by the Iberian and Ebro massifs (Fig. 2A; Philip et al., 2000). The sediments are predominantly shallow marine carbonates deposited on platforms along the northern Ebro Massif and western Massif Central, and referred to as the Aquitaine platform (Fig. 2A). Hemipelagic sediments are found in the Bay of Biscay that formed the basin during the Cenomanian (Fig. 2A). The northern part of the Aquitaine platform is a stable domain where maximum burial occurred during the Late Cretaceous, corresponding to 550-m-thick deposits overlying the Cenomanian formations (Platel, 1996). The Turonian/Coniacian boundary is marked by substantial detritic discharge corresponding to local deformations (Platel, 1987). The Cenozoic is characterized by uplift that caused denudation and imparted its present configuration to the Aquitaine Basin (Biteau et al., 2006).

The mid-Cretaceous (120-80 Ma) was one of the warmest periods of Phanerozoic history and characterized by high atmospheric $\mathrm{CO}_{2}$ levels, high tropical sea surface temperatures accompanied by relatively low latitudinal temperature gradients, high sea levels, and high faunal and floral turnovers (Haq et al., 1987; Pucéat et al. 2007; Gertsch et al., 2010).

The highest sea levels during the Cretaceous were reached during Cenomanian-Turonian times. The maximum flooding surface, corresponding to the major transgression that affected the Cretaceous from the Berriasian to the Turonian, is recorded in lower Turonian deposits (Moreau, 1996; Hardenbol et al., 1998). The northern part of the Aquitaine platform gradually flooded during the Cenomanian as attested to by 75 -m-thick limestones, marls, and clayey marine deposits (Platel, 1996). Bourgeuil et al. (1970) describe the Cenomanian lithology and paleontology of the Angoulême region in the northern Aquitaine Basin. The lower Cenomanian formations, directly overlying the late Jurassic deposits, can be divided into two lithological units (Fig. 2B): (1) black clays to bluish marls ("Argiles Lignitifères de Coquand" Formation) and (2) a detrital horizon including glauconitic sands, sandstones, and limestones ("Grès et Sables Verts" Formation). The middle Cenomanian deposits correspond mainly to the "Premier Niveau de Calcaire à Rudistes" Formation (Fig. 2B), which includes both argillaceous limestones and limestones with foraminifera, rudists (Ichthyosarcolites), and echinoid spicules. The late Cenomanian deposits can be subdivided into three lithological units (Fig. 2B). The "Argiles tégulines de Coquand" Formation at the base are bluish marls, rich in oysters and locally pyrite-rich. The "Sables supérieurs à Pycnodontes" Formation is composed mostly of quartz and mica-rich sands. The "Second niveau de calcaire à rudistes" Formation, at the top, is made up of well cemented, thin laminated detrital limestones.

The "Grès et Sables Verts", "Premier Niveau de Calcaire à Rudistes" and "Argiles tégulines de Coquand" Formations correspond to the lithostratigraphic units B, C and D described by Moreau (1993; Fig. 2B and Fig. 3). Francis (1984) correlated the lithostratigraphic units of the northern Aquitaine platform with the Sarthe Formations using ammonite, foraminifer and ostracod biostratigraphy. He correlated the B2 and B3 (Figs. 2B and 3) sub- 


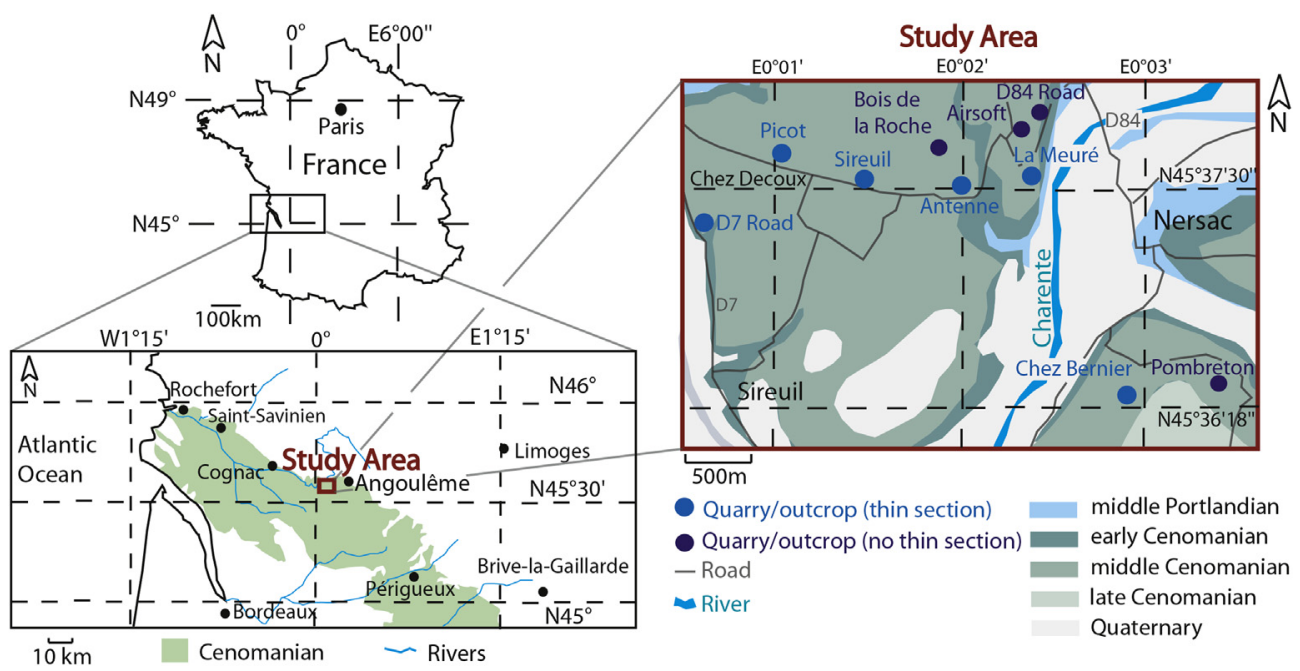

Fig. 1. Location of the study outcrops and quarries on a simplified geological map of the northern part of the Aquitaine Basin.

units with the "Sables et Grès de la Trugalle et de Lamnay" Formation, the $\mathrm{C}$ unit with the "Sables et Grès du Mans" and "Sables du Perche" Formations, and the D unit with the "Marnes à Ostrea biauriculata" Formation. Francis (1984) and Platel (1996) suggest the occurrence of 4 regionally-developed hardgrounds at the B-C, $\mathrm{C}-\mathrm{D}, \mathrm{F}-\mathrm{G}$ and $\mathrm{G}-\mathrm{H}$ unit boundaries, extending from the northern Aquitaine platform to the western Sarthe. The hardgrounds are present on the top of cycles displaying a decrease of the terrigenous/carbonate sediment ratio and an increase of the coarse grains proportion upwardly (Francis, 1984). There is abundant evidence of strong current activity at the termination of each cycle. These hardgrounds are commonly glauconitized and may be overlain by phosphatized nodules and fossils fragments. The sedimentological description strongly suggests that hardground development represents the culmination of a shoaling episode (Francis, 1984). The correlation of four major hardgrounds between the Aquitaine and Paris basins proposed by Francis (1984) indicates that a eustatic control might be implicated in their development. Local hardgrounds also develop in the northern Aquitaine platform. Their origin is associated with local effects such as deposition over "swells" or changes in water depth associated with tectonism (Francis, 1984). The Cenomanian deposits record three secondorder hemicycles (Fig. 2B, Hardenbol et al., 1998). The transgressive hemicycle $\mathrm{C} 1$ extends from the top of the Jurassic limestones, separated from Cenomanian limestones by an erosional discontinuity, to the maximum flooding surface in the "Argiles lignitifères de Coquand" Formation. The regressive hemicycle C2 extends from the maximum flooding surface to the "Premier Niveau de Calcaire à Rudistes" Formation. The transgressive hemicycle C3 ends in the lower Turonian "Calcaires argileux à Exogyra" Formation. These second-order hemicycles encompass five third-order cycles: $C_{A}, C_{B}, C_{C}, C_{D}$ and $C_{E}$ (Fig. 2B, Platel, 1996). The ammonite biozonation for the northern Aquitaine platform (Moreau et al., 1983, Moreau, 1996), coupled with the benthic foraminifer faunal associations defined by Moreau (1996) were used to establish a reliable biostratigraphical framework for the sedimentary sections (Fig. 3). The ammonites are very rare and only 40 specimens have been studied from the Atlantic coast to Angoulême (Moreau et al., 1983). The oldest specimen found in the northern Aquitaine Cenomanian platform is Engonoceras sp., but this ammonite does not allow a reliable attribution to a precise biozone of the "Grès et Sables verts" Formation (Moreau et al., 1983). The ammonite (Acanthoceras (Acanthoceras) pseudorenevieri, Moreau et al., 1983) coming from the top of the $B_{3}$ sub-unit at Rioux (Charente-Maritime; Fig. 3) provides the oldest precise biozonation attribution. This ammonite indicates the early part of the middle Cenomanian, and can be attributed either to the early part of the Acanthoceras rhotomagense Zone or to the Cunningtoniceras inerme Zone (Moreau et al., 1983, Fig. 3). There is no evidence for the presence of the Cunningtoniceras inerme Zone in the study area, but this biozone is referenced in Maine above the Rouen hardground (Robaszynski et al., 1998). Calycoceras cenomanense occurs in the uppermost part of the unit $C$ at the Port-des-Barques (Charente-maritime) and indicates the Acanthoceras jukesbrownei Zone (Moreau et al., 1983; Fig. 3). The "Argiles tégulines de Coquand" Formation (unit D) has yielded Thomelites cf. lattense near Angoulême (Charente), indicating an early late Cenomanian level (Calycoceras guerangeri Zone; Moreau et al., 1983; Fig. 3). The unit $G$ has yielded Neolobites vibrayeanus at Port-des-Barques (Charente-Maritime), suggesting a high Cenomanian level but probably below the Metoicoceras geslinianum Zone (Moreau et al., 1983; Fig. 3). The top of the unit G has yielded Calycoceras (Calycoceras) naviculare and Calycoceras geslinianum (Moreau et al., 1983; Fig. 3). These ammonites indicate the Metoicoceras geslinianum Zone (Moreau et al., 1983; Fig. 3). The middle-late Cenomanian boundary is located in the lower part of the "Argiles tégulines de Coquand" Formation (unit D, Fig. 3). The early part of the middle Cenomanian is indicated by Acanthoceras (Acanthoceras) pseudorenevieri at the top of the B3 sub-unit, where is probably located the early-middle Cenomanian boundary (Moreau, 1993; Fig. 3).

Moreau et al. (1978) and Moreau $(1993,1996)$ studied the distribution of 24 benthic foraminifer species, much more abundant than ammonites on the northern Aquitaine platform. Three benthic foraminifer biozones were defined by Moreau $(1993,1996)$ for the Cenomanian. As for ammonite, foraminifers were attributed to the lithostratigraphic units of the northern Aquitaine platform defined by Moreau (1993). There are no early Cenomanian ammonites discovered for the northern Aquitaine platform. However, Moreau et al. (1978), Moreau (1993, 1996), Platel (1996) and Meunier et al. (1999) described an Orbitolina association (O. concava and $O$. conica) coupled with Simplalveolina simplex, in the $\mathrm{B}_{1}$ sub-unit ("Grès et sables verts" Formation), which is typical of the early Cenomanian (Fig. 3). This Orbitolina association is also recognized by Francis (1984) and Juignet et al. (1974) as a useful biostratigraphic guide to the position of the terminal early Cenomanian on the both sides of the Straits of Poitou. The $C$ unit is characterized by a middle Cenomanian association: Ovalveolina ovum and Praealveolina cretacea (Moreau et al., 1978; Moreau, 1993, 1996; Platel, 

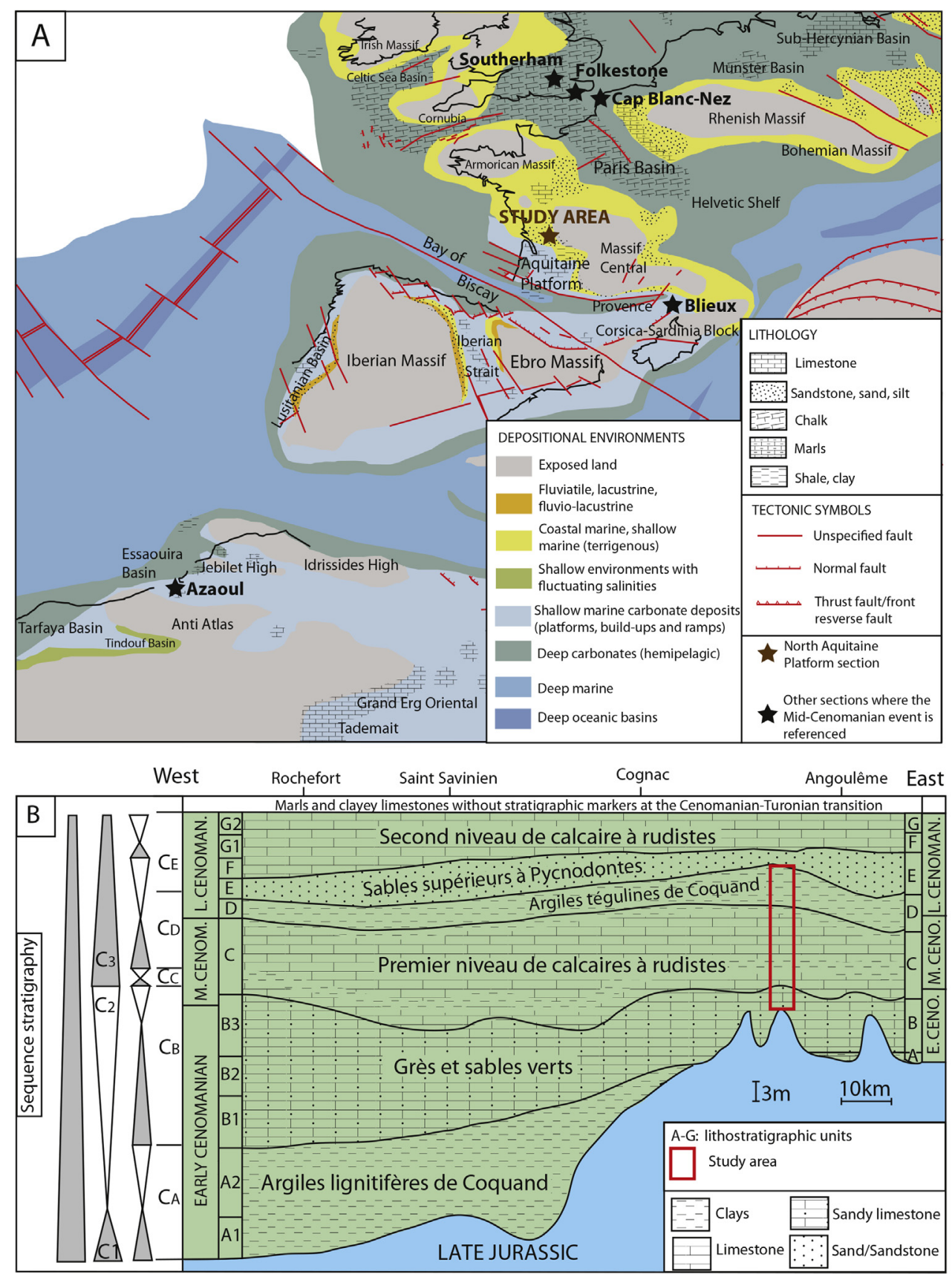

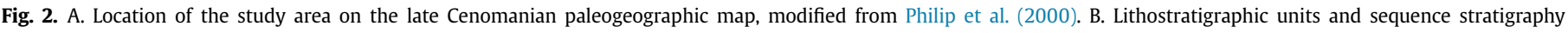
framework of the Cenomanian deposits of the northern Aquitaine Basin, modified from Moreau (1996), Platel (1996), and Hardenbol et al. (1998).

1996; Fig. 3). The appearance of this foraminifer association occurs in the B3 sub-unit and can be correlated with the occurrence of Acanthoceras (Acanthoceras) peudorenevieri which indicates the early middle Cenomanian. The first occurrence of the Ovalveolina and Praealveolina association is correlated in the Poitou with the beginning of the middle Cenomanian, well-dated with ammonite fauna (Juignet et al., 1974). It allows a reliable location of the earlymiddle Cenomanian boundary in the B3 sub-unit, in the upper part of the "Grès et Sables Verts" Formation (Fig. 3). The late Cenomanian is characterized by the predominance of Prealveolina cretacea on the entire platform (Moreau, 1996).

According to the abundance of Tenua and Hystrichosphaeridium and the occurrence of the Guembelitria harrisi, Globigerinelloides cf. aegelfordensis and Hedbergella planispira planktonic foraminifer association, Moreau (1977, 1996) attributed the A unit ("Argiles lignitifères de Coquand" Formation) to the early Cenomanian.

The correlation between foraminifers associations and ammonite occurrences allow the definition of a precise biostratigraphical framework (at the ammonite biozone scale), as in the standard Cenomanian ammonite zonal scheme (Hardenbol et al., 1998; Fig. 3).

\section{Material and methods}

\subsection{Sedimentology}

Eight underground quarries (1) le Picot (Pi), (2) Sireuil (Si), (3) l'Antenne (An), (4) le Bois de la Roche (BR), (5) la Meuré (M), (6) 


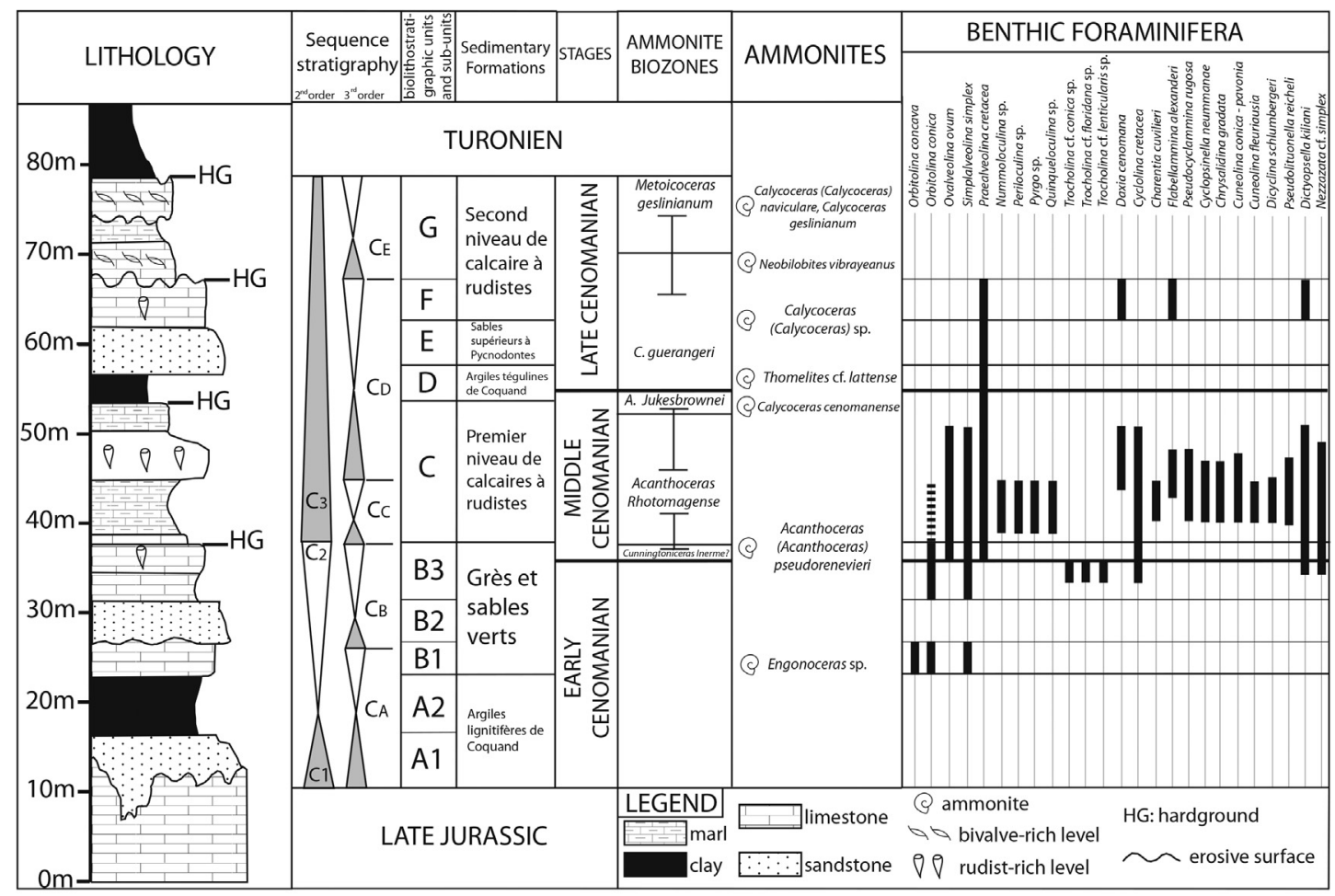

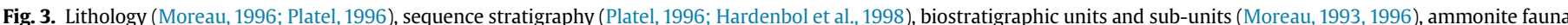

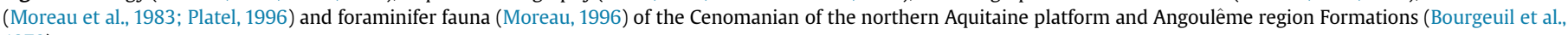
1970).

Airsoft (Ar), (7) Chez Bernier (CB) and (8) Pombreton (Pb), two outcrop sections (D7 and D84) and nine boreholes have been studied (Fig. 1). In all 19 sedimentary logs showing lithology, texture, allochem content, and sedimentary structures were drawn. Some 52 thin-sections were made from the 201 samples collected along the sedimentary logs: five from SC4 cores, four from SC5 cores, five from SC6 cores, six from SC7 cores, six from Sireuil quarry, seven from le Picot quarry, five from l'Antenne quarry, four from la Meuré quarry, five from Chez Bernier quarry, and three from the D7 road outcrop.

On the basis of thin-section descriptions using light microscopy, different variables were visually quantified to characterize the microfacies including grain type, texture, granulometry, and sorting. Porosity was calculated using jmicrovision software. Four photographs were taken of each thin section with LAZ EZ software and assembled on Photoshop. The blue proportion (color of the resin injected into the porosity) in each view could then be measured with jmicrovision. Rudist shells and diagenetic cements were examined under cathodoluminescence microscope. Cathodoluminescence analyses were carried out on a cold-cathode, operating at $14 \mathrm{kV}$ and at $100-200 \mu \mathrm{A}$, coupled to an Olympus microscope BX41.

\subsection{Sequence stratigraphy}

Following the definition of Embry (2009), sequence stratigraphic interpretations were integrated into seven logs to reconstruct a stratigraphic cross-section. In this sequence stratigraphy model, units are bounded either by a subaerial unconformity (SU) when the surface was exposed, or by a maximum regressive surface (MRS) when the surface was not exposed. Maximum regressive surfaces coincide with a shift from a shallowing-upward to a deepening-upward pattern (Embry, 2009) and have been called transgressive surfaces (Van Wagoner et al., 1988). Maximum flooding surfaces (MFSs) mark the shift from deepening-upward to shallowing-upward patterns of the depositional sequences defined in this study. Subaerial unconformities or maximum regressive surfaces form sequence boundaries (SBs). Depositional sequences are composed of transgressive and regressive systems tracts (TSTs and RSTs). The transgressive systems tract is characterized by retrograding structures, with more distal facies upwardly and the regressive systems tract is characterized by prograding structures, with more proximal facies upwardly.

\subsection{Geochemistry}

Stable carbon and oxygen values of dental micro-drilled sparry calcite, rudists, and micrite samples were used to reconstruct the mid-Cenomanian $\delta^{13} \mathrm{C}$ curve and to evaluate the potential diagenetic influence. Carbonate powders of micrite samples $(\mathrm{n}=34)$ and grainstone samples $(n=4)$ were reacted with $100 \%$ orthophosphoric acid at $25^{\circ} \mathrm{C}$ and the $\mathrm{CO}_{2}$ gas given off was analyzed using a VG Sira 10 mass spectrometer to determine $O$ and $C$ isotope compositions at the GEOPS laboratory (Université Paris-Sud, Orsay). Reproducibility was checked by replicate analysis of laboratory standards and was $\pm 0.1 \%$ for oxygen and carbon isotopes alike.

Carbonate powders of sparry calcite $(\mathrm{n}=35)$ and rudists $(\mathrm{n}=4)$ were reacted with $100 \%$ phosphoric acid at $75{ }^{\circ} \mathrm{C}$ using a Kiel I prototype dual inlet line connected to a ThermoFinnigan 251 mass spectrometer. Reproducibility was checked by replicate analysis of laboratory standards and was $\pm 0.2 \%$ ( $1 \sigma)$ for oxygen isotopes and $\pm 0.1 \%$ o $(1 \sigma)$ for carbon isotopes.

All isotope values are reported in the standard $\delta$-notation in per mil relative to V-PDB (Vienna Pee Dee Belemnite) by assigning a $\delta^{13} \mathrm{C}$ value of $+1.95 \%$ and a $\delta^{18} \mathrm{O}$ value of $-2.20 \%$ to NBS19. 


\section{Results}

\subsection{Sedimentary facies}

The limestones under study were sorted into 15 different facies, which were then arranged into four facies associations. These four facies associations are typical of four depositional environments ranging from lower offshore to backshore (Fig. 4). Observations and descriptions are summarized in Table 1. A composite sedimentological log of the Cenomanian rocks from Rocamat cores at Sireuil quarry (SC5 and SC6 boreholes) is proposed to characterize the stratigraphic succession (Fig. 5).

The four facies associations reflect the following four depositional settings: (1) lower offshore for facies deposited below the storm wave base (facies association FA1), (2) upper offshore for facies deposited between the storm wave base and the fair-weather wave base (facies association FA2), (3) shoal/barrier environments for wave- and tide-dominated facies deposited above the fairweather wave base (facies association FA3), (4) lagoon to backshore environments for mud-supported facies and lignite layers (facies association FA4).

\subsubsection{Facies association FA1 (lower offshore)}

This facies association contains (1) clayey facies (facies F1a, Fig. 6A), (2) marls (facies F1b, Fig. 6A) and (3) a beige mudstone with fine clayey lamina (facies F1c, Fig. 6B). These facies contain various microfauna and macrofauna in very small amounts. Fauna are composed of bivalves, especially oysters such as Exogyra Columba major, small benthic foraminifera (Flabellammina, Daxia, Haplophragmoides, Ammobaculites), planktonic foraminifera (Guembelitria, Hedbergella, and Praeglobotruncana), nautilus, and echinoids Hemiaster and Periaster (Moreau, 1996). The very fine granulometry and the absence of sedimentary structures within these facies indicate a very calm depositional environment, probably below the storm wave base.

\subsubsection{Facies association FA2 (upper offshore)}

Facies association FA2 contains two limestone facies: (1) pellet and echinoderm wackestone/packstone (facies F2a, Fig. 7A and B) and (2) pellet and echinoderm packstone/grainstone alternating with marl interbeds (facies F2b, Fig. 7C and D). In this facies association, the dominant fauna are echinoderms, bivalves, miliolids, and bryozoans, which indicate normal oxygenation and salinity, or quite deep water. Carbonate grains and bioclasts are moderatelysorted with sizes ranging from $100 \mu \mathrm{m}$ to $1 \mathrm{~mm}$. The accumulation of fragmented bivalve shells together with local observations of shell-graded-layers and gutter casts suggest sedimentation under storm influences in an upper offshore environment between the storm wave base and the fair-weather wave base.

\subsubsection{Facies association FA3 (shoal environment)}

Facies association FA3 contains seven facies: (1) a coarse and poorly sorted bioclastic grainstone rich in echinoderms, bivalves, and bryozoans (facies F3a, Fig. 8A); (2) a fine and well-sorted echinoderm grainstone facies with high porosity (facies F3b, Fig. 8B and C); (3) a well cemented, fine and very well-sorted grainstone, rich in echinoderms and miliolids (facies F3c, Fig. 8D); (4) a well cemented echinoderm, peloid, and Praealveolina facies with low porosity (facies F3d, Fig. 8E); (5) an oolitic grainstone facies (facies F3e, Fig. 8F), (6) a very poorly sorted grainstone to rudstone facies, rich in rudists (facies F3f, Fig. 8G) and (7) a glauconite and quartz sandstone.

In facies association FA3, the presence of echinoderms and bryozoans in various proportions depending on the facies suggests well-oxygenated water with normal salinity.

All these facies are grainstones and exhibit sigmoid crossbedding sets of megaripples indicating shallow, high-energy, wave-dominated conditions in a shoreface environment. Locally, megaripples forming herringbones can be observed (Fig. 8C), suggesting possible periods of tidal influences.

\subsubsection{Facies association FA4 (protected lagoon to backshore)}

Three facies are distinguished in facies association FA4: (1) a rudist rudstone (facies F4a, Fig. 9A-C), (2) a foraminifer/rudist packstone to rudstone (facies F4b, Fig. 9D), and (3) lignite layers (facies F4c). In facies F4a and F4b, the fauna is mainly rudists and benthic foraminifera such as miliolids and very well-preserved Praealveolina. These facies also contain echinoderms, bryozoans, gastropods, and coral debris. In these mud-supported facies, the presence of peloidal texture and the very well-preserved Praealveolina sp. and gastropods are indicative of a protected lagoon environment. Rudists are rarely found in life position but they can locally form bioherms of Durania in facies F4a (Moreau, 1996). In facies F4c, organic matter and very fine granulometry suggest a very calm and protected depositional environment. The carbonate content in facies $\mathrm{F} 4 \mathrm{C}$ is lower than carbonate content in the marls (facies F1b) of the Cc sequence (Fig. 6A). In this backshore environment, organic matter accumulation may have given rise to lignite layers.

\subsection{Facies architecture and depositional sequences}

Three third-order depositional sequences $\left(C_{B}, C_{C}\right.$, and $\left.C_{D}\right)$ were recognized from the "Grès et sables verts" Formation (early Cenomanian) to the "Argiles tégulines de Coquand" Formation (late Cenomanian). Considering this interval lasted approximately $4 \mathrm{My}$, the average duration of each cycle is about $1.3 \mathrm{My}$ (Gradstein et al., 2004), which is in the range of duration for third-order cycles (1-10 My; Schlager, 2004). The sedimentary logs and the sequence stratigraphic interpretations are summarized in Fig. 10.

\subsubsection{The $C_{B}$ sequence (early to mid-Cenomanian)}

This sequence is included in the "Grès et sables verts" Formation. The maximum flooding surface is found in the D7 road outcrop only (Fig. 10) and is characterized by mud-supported limestones rich in pellets. The shallowing trend, corresponding to

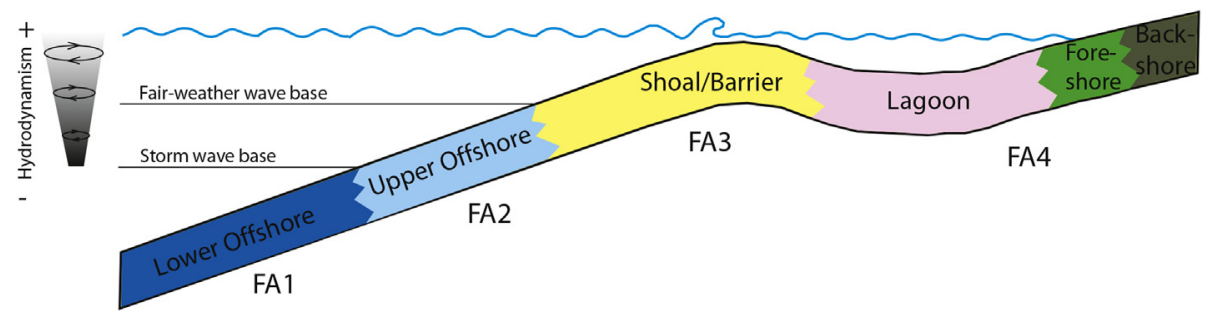

Fig. 4. Depositional model of the Cenomanian facies associations (FA) and its location from the lower offshore to backshore in the Aquitaine Basin. 
Table 1

Facies associations, lithofacies, non-bioclastic, and bioclastic components, sedimentary and biogenic structures, granulometry, sorting, and paleoenvironmental interpretations of the Cenomanian carbonates of a part of the north Aquitaine Basin.

\begin{tabular}{|c|c|c|c|c|c|c|}
\hline Facies association & Lithofacies & Non-bioclastic components & Bioclastic components & $\begin{array}{l}\text { Sedimentary and biogenic } \\
\text { structures }\end{array}$ & Granulometry and sorting & $\begin{array}{l}\text { Energy and depositional } \\
\text { environment }\end{array}$ \\
\hline \multirow[t]{3}{*}{ FA1: Lower offshore } & F1a: clays & & $\begin{array}{l}\text { Benthic and planktonic } \\
\text { foraminifera }(R) \text {, oysters }(R), \\
\text { nautilus }(R), \text { echinoids }(R)\end{array}$ & & Very well sorted; $<4 \mu \mathrm{m}$ & $\begin{array}{l}\text { Very low energy, lower } \\
\text { offshore }\end{array}$ \\
\hline & F1b: marls & & $\begin{array}{l}\text { Benthic and planktonic } \\
\text { foraminifera }(R) \text {, oysters }(R), \\
\text { nautilus }(R), \text { echinoids }(R)\end{array}$ & & Very well sorted & $\begin{array}{l}\text { Very low energy, lower } \\
\text { offshore }\end{array}$ \\
\hline & $\begin{array}{l}\text { F1c: mudstone with } \\
\text { bivalves }\end{array}$ & Silt (R) & $\begin{array}{l}\text { Bivalves }(\mathrm{R}) \text {, benthic } \\
\text { foraminifera }(\mathrm{R})\end{array}$ & Local clay laminae & Very well sorted & $\begin{array}{l}\text { Very low energy, lower } \\
\text { offshore }\end{array}$ \\
\hline \multirow[t]{2}{*}{ FA2: Upper offshore } & $\begin{array}{l}\text { F2a: wacke/packstone with } \\
\text { pellets/peloids and } \\
\text { echinoderms }\end{array}$ & Pellets (F), glauconite (R) & $\begin{array}{l}\text { Echinoderms (F), bivalves } \\
\text { (C), miliolids (C), bryozoans } \\
\text { (R) }\end{array}$ & Shell-graded layers & $\begin{array}{l}\text { Moderately sorted, } 100 \\
-300 \mu \mathrm{m} \text {, some elements } \\
\sim 1 \mathrm{~mm}\end{array}$ & $\begin{array}{l}\text { Moderate to low energy, } \\
\text { upper offshore }\end{array}$ \\
\hline & $\begin{array}{l}\text { F2b: alternations between } \\
\text { marls and pack/grainstone } \\
\text { with pellets/peloids and } \\
\text { echinoderms }\end{array}$ & $\begin{array}{l}\text { Pellets }(F) \text {, peloids }(C) \text {, } \\
\text { glauconite }(R)\end{array}$ & $\begin{array}{l}\text { Echinoderms }(\mathrm{F}) \text {, miliolids } \\
\text { (C), bivalves }(\mathrm{C})\end{array}$ & $\begin{array}{l}\text { Gutter casts, shell graded } \\
\text { layers }\end{array}$ & $\begin{array}{l}\text { Moderately sorted, } 200 \\
-600 \mu \mathrm{m}\end{array}$ & $\begin{array}{l}\text { Moderate to low energy, } \\
\text { upper offshore }\end{array}$ \\
\hline \multirow[t]{7}{*}{ FA3: Shoreface } & $\begin{array}{l}\text { F3a: coarse bioclastic } \\
\text { grainstone }\end{array}$ & $\begin{array}{l}\text { Oolites }(R) \text {, intraclasts }(R), \\
\text { pellets }(R) \text {, peloids }(R)\end{array}$ & $\begin{array}{l}\text { Echinoderms (F), bryozoans } \\
\text { (F), bivalves (F), miliolids } \\
\text { (C), corals (R), brachiopods } \\
\text { (R) }\end{array}$ & $\begin{array}{l}\text { Sigmoid cross-bedding } \\
\text { megaripples }\end{array}$ & $\begin{array}{l}\text { Poorly sorted, } 500 \mu \mathrm{m} \\
-2 \mathrm{~mm}\end{array}$ & $\begin{array}{l}\text { High energy, shoreface, } \\
\text { wave dominated }\end{array}$ \\
\hline & F3b: echinoderm grainstone & $\begin{array}{l}\text { Pellets }(R), \text { peloids }(R), \\
\text { intraclasts }(R)\end{array}$ & $\begin{array}{l}\text { Echinoderms }(A) \text {, bivalves } \\
(\mathrm{F}) \text {, foraminifera }(\mathrm{R}) \text {, } \\
\text { bryozoans }(\mathrm{R}) \text {, coral } \\
\text { fragments }(\mathrm{R}) \text {, brachiopods } \\
(\mathrm{R})\end{array}$ & $\begin{array}{l}\text { Sigmoid cross-bedding } \\
\text { stratifications in } \\
\text { megaripples, herring bone } \\
\text { stratifications }\end{array}$ & $\begin{array}{l}\text { Well sorted, } 300 \mu \mathrm{m} \\
-700 \mu \mathrm{m}\end{array}$ & $\begin{array}{l}\text { High energy, shoreface, tide } \\
\text { dominated }\end{array}$ \\
\hline & $\begin{array}{l}\text { F3c: echinoderm and } \\
\text { miliolid grainstone }\end{array}$ & $\begin{array}{l}\text { Pellets }(C) \text {, peloids }(R) \text {, } \\
\text { quartz }(R) \text {, superficial ooids } \\
(R)\end{array}$ & $\begin{array}{l}\text { Echinoderms }(F) \text {, miliolids } \\
(\mathrm{F}) \text {, bivalves }(\mathrm{C})\end{array}$ & Bioturbations & $\begin{array}{l}\text { Very well sorted, about } \\
200 \mu \mathrm{m}\end{array}$ & $\begin{array}{l}\text { High energy, shoreface, } \\
\text { wave dominated }\end{array}$ \\
\hline & $\begin{array}{l}\text { F3d: echinoderm and } \\
\text { praealveolina grainstone }\end{array}$ & $\begin{array}{l}\text { Peloids }(C) \text {, pellets }(R) \text {, } \\
\text { quartz }(R)\end{array}$ & $\begin{array}{l}\text { Echinoderms }(\mathrm{F}) \text {, } \\
\text { praealveolina }(\mathrm{F}) \text {, bivalves } \\
(\mathrm{F})\end{array}$ & $\begin{array}{l}\text { Sigmoid cross-bedding } \\
\text { stratifications, herring bone } \\
\text { stratifications }\end{array}$ & Well sorted, $300-700 \mu \mathrm{m}$ & $\begin{array}{l}\text { High energy, shoreface, tide } \\
\text { dominated }\end{array}$ \\
\hline & F3e: oolitic grainstone & $\begin{array}{l}\text { Ooids }(A) \text {, peloids }(C) \text {, } \\
\text { intraclasts }(C) \text {, aggregates } \\
(R) \text { quartz }(R) \text {, glauconite }(R)\end{array}$ & $\begin{array}{l}\text { Coral fragments }(C) \text {, } \\
\text { echinoderms }(C) \text {, } \\
\text { Foraminifera }(C) \text {, bivalves } \\
(R), \text { bryozoans }(R)\end{array}$ & $\begin{array}{l}\text { Sigmoid cross bedding } \\
\text { stratifications in } \\
\text { megaripples }\end{array}$ & $\begin{array}{l}\text { Moderately sorted, } 300 \\
-500 \mu \mathrm{m} \text {, some elements } \\
\sim 1 \mathrm{~mm}\end{array}$ & $\begin{array}{l}\text { Very high energy, shoreface } \\
\text { (oolitic shoal) }\end{array}$ \\
\hline & $\begin{array}{l}\text { F3f: grainstone to rudstone } \\
\text { with echinoderms, rudists, } \\
\text { and peloids }\end{array}$ & $\begin{array}{l}\text { Peloids (F), Quartz (C), } \\
\text { Glauconite (R) }\end{array}$ & $\begin{array}{l}\text { Echinoderms }(F) \text {, rudists }(F) \text {, } \\
\text { foraminifera }(C) \text {, red algae } \\
(R)\end{array}$ & Megaripples & $\begin{array}{l}\text { Poorly sorted, } 300 \mu \mathrm{m} \\
-2 \mathrm{~mm} \text {, decimetric rudists }\end{array}$ & $\begin{array}{l}\text { Very high energy, shoreface } \\
\text { (rudist reef) }\end{array}$ \\
\hline & $\begin{array}{l}\text { F3g: Glauconite and quartz } \\
\text { sandstone }\end{array}$ & $\begin{array}{l}\text { Quartz (A), glauconite }(F) \text {, } \\
\text { hematite }(C)\end{array}$ & Bivalves (R) & Cross-bedding & $\begin{array}{l}\text { Moderately sorted } 500 \mu \mathrm{m} \\
-1 \mathrm{~mm}\end{array}$ & $\begin{array}{l}\text { High energy shoreface, } \\
\text { wave-dominated }\end{array}$ \\
\hline \multirow[t]{3}{*}{$\begin{array}{l}\text { FA4: Protected lagoon to } \\
\text { backshore }\end{array}$} & $\begin{array}{l}\text { F4a: Rudist rudstone to } \\
\text { floatstone }\end{array}$ & Peloids (R), quartz (R) & $\begin{array}{l}\text { Rudists/bivalves (A), } \\
\text { echinoderms }(C), \text { bryozoans } \\
(R) \text { gasteropods }(R), \\
\text { brachiopods }(R) \text {, } \\
\text { foraminifera(R), Durania } \\
\text { bioherms }(R)\end{array}$ & $\begin{array}{l}\text { Peloidal structures, } \\
\text { microbial laminae }\end{array}$ & $\begin{array}{l}\text { Very poorly sorted, } 200 \mu \mathrm{m} \\
\text { to several decimeters }\end{array}$ & Low energy lagoon \\
\hline & $\begin{array}{l}\text { F4b: Foraminifera and } \\
\text { rudist packstone to } \\
\text { rudstone }\end{array}$ & $\begin{array}{l}\text { Intraclasts }(R) \text { peloids }(R) \text {, } \\
\text { quartz }(R)\end{array}$ & $\begin{array}{l}\text { Rudists/bivalves }(A) \text {, } \\
\text { foraminifera }(A) \text {, } \\
\text { echinoderms }(R) \text {, } \\
\text { gasteropods }(R), \text { bryozoans } \\
\text { (R), coral fragments }(R)\end{array}$ & $\begin{array}{l}\text { Peloidal structures, } \\
\text { microbial laminae }\end{array}$ & $\begin{array}{l}\text { Very poorly sorted, } 200 \mu \mathrm{m} \\
\text { to several millimeters }\end{array}$ & $\begin{array}{l}\text { Low energy, possible storm } \\
\text { washover deposits in } \\
\text { lagoon }\end{array}$ \\
\hline & $\begin{array}{l}\text { F4c: carbonaceous dark } \\
\text { clays }\end{array}$ & & & & Very well sorted; $<4 \mu \mathrm{m}$ & Very low energy, backshore \\
\hline
\end{tabular}




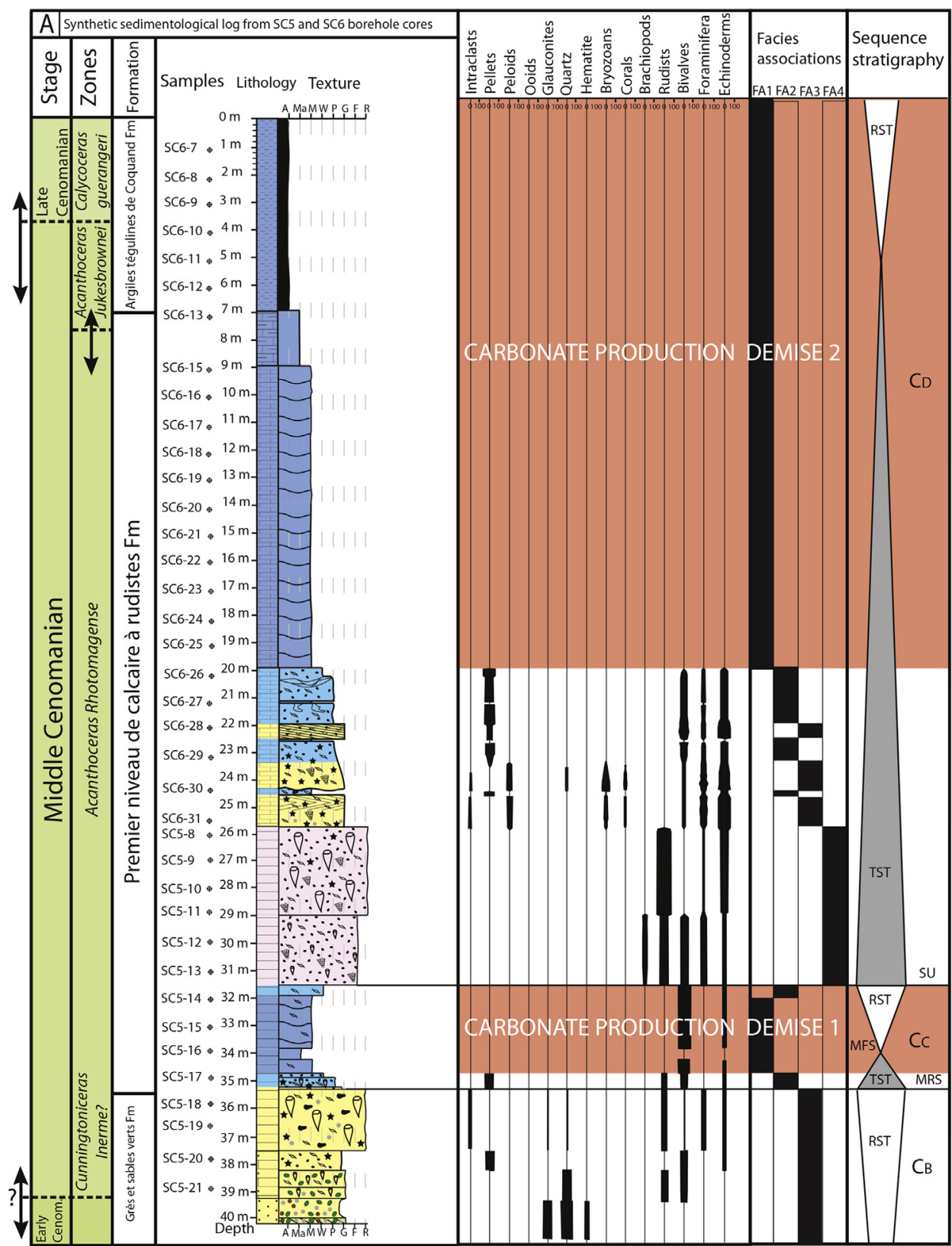

\begin{tabular}{|c|c|c|c|c|c|c|c|c|}
\hline$B$ & \multicolumn{4}{|c|}{ Allochems and minerals } & \multicolumn{4}{|c|}{ Fauna } \\
\hline \multirow{6}{*}{ 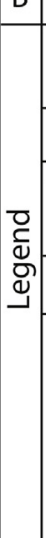 } & $\begin{array}{c}\text { (a) Oolite } \\
-: \text { Pellet }\end{array}$ & $\begin{array}{ll}\text { - } & \text { Peloid } \\
\text { - } & \text { Lithoclast } \\
\end{array}$ & $\begin{array}{l}\text { - Glauc } \\
\text { - Hema } \\
\text { - Quart }\end{array}$ & & $\begin{array}{l}\mathrm{Ech} \\
\qquad \mathrm{Biv}\end{array}$ & $\begin{array}{l}\text { hoderm } \\
\text { ve }\end{array}$ & $\begin{array}{l}\text { Foraminifera } \\
\text { Bryozoan * }\end{array}$ & $\begin{array}{l}\theta \text { Rudist } \\
\text { Coral fragment }\end{array}$ \\
\hline & \multicolumn{4}{|c|}{ Texture } & \multicolumn{4}{|c|}{ Lithology } \\
\hline & $\begin{array}{l}\text { C:Clay } \\
\text { Ma:Marl } \\
\text { M:Mudstone }\end{array}$ & $\begin{array}{l}\text { W:Wackestone } \\
\text { P:Packstone } \\
\text { G:Grainstone }\end{array}$ & \multicolumn{2}{|c|}{$\begin{array}{l}\text { F: Floatstone } \\
\text { R:Rudstone }\end{array}$} & 高: & $\begin{array}{l}\text { Limestone } \\
\text { Sandstone }\end{array}$ & 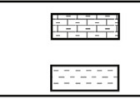 & $\begin{array}{l}\text { Marl } \\
\text { Clay }\end{array}$ \\
\hline & \multicolumn{3}{|c|}{ Biogenic and sedimentary structures } & \multicolumn{5}{|c|}{ Depositional environment } \\
\hline & \multirow{2}{*}{\multicolumn{3}{|c|}{$\begin{array}{ll}\text { 2 } & \text { planar cross bedding } \\
\text { bioturbations }\end{array}$}} & \multicolumn{2}{|c|}{ continent } & inner ramp & mid ramp & outer ramp \\
\hline & & & & \multicolumn{2}{|c|}{ backshore } & lagoon & $\begin{array}{l}\text { upper } \\
\text { offshore }\end{array}$ & $\begin{array}{l}\text { lower } \\
\text { offshore }\end{array}$ \\
\hline
\end{tabular}

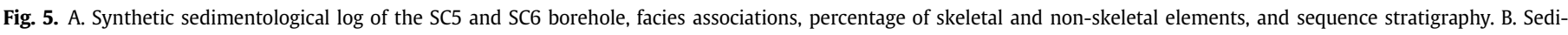
mentological log legends. 

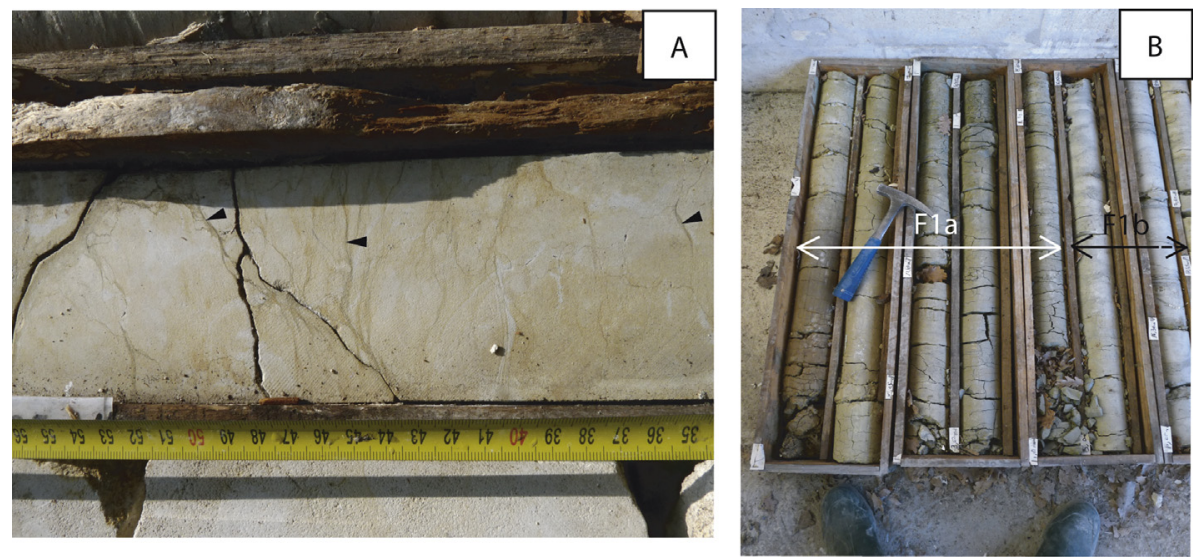

Fig. 6. A. Beige mudstone with clay lamina - F1c - Borehole SC7. B. Clays and Marls - F1a and F1b - Borehole SC7.

the regressive systems tract, is characterized by a vertical facies evolution from 2-m-thick pellet and peloid packstone facies (D7 road outcrop, facies F2b, Fig. 10) to 2 m-thick bioclastic cemented rudstone rich in rudists, echinoderms, intraclasts, and quartz (F3f, Figs. 5A and 10). The depositional model may be a low dipping ramp prograding to the south-west during the regressive systems tract (Figs. 10 and 11A). The upper boundary of the $C_{B}$ sequence is a maximum regressive surface, characterized by a sudden facies change from well cemented rudist rudstone (F3f) to marly facies several meters thick (facies F1c-b) reflecting rapid deepening. It corresponds to the top of a second-order regressive cycle in European basins (Hardenbol et al., 1998). The upper boundary of the $C_{B}$ sequence is marked by a regionally-developed hardground, in northern Aquitaine and Sarthe (Francis, 1984; Platel, 1996). In our study area the top of the $C_{B}$ sequence corresponds to a wellcemented and very coarse rudists rudstone (facies F3f). The presence of megaripples suggests a deposition in a high energy wave-dominated shoreface (Table 1). In thin section, this facies displays glauconite, calcareous algae, dissolution and welldeveloped isopachous bladed early cement. This early isopachous cement is mainly located a few decimeters below the maximum regressive surface, where it contributed to early lithification during sedimentary gaps associated with submarine hardground, as documented in the Middle Jurassic Burgundian platform (Purser, 1969; Durlet and Loreau, 1996; Brigaud et al., 2009). This hardground underlines a facies change from shoal (facies F3f) to more open marine facies (facies F2b).

\subsubsection{The $C_{C}$ sequence (mid-Cenomanian)}

The $\mathrm{C}_{\mathrm{C}}$ sequence in the middle Cenomanian "Premier niveau de calcaire à rudistes" Formation (Figs. 5A and 10) comprises three different facies: marls (facies F1b), bivalve mudstones (F1c), and
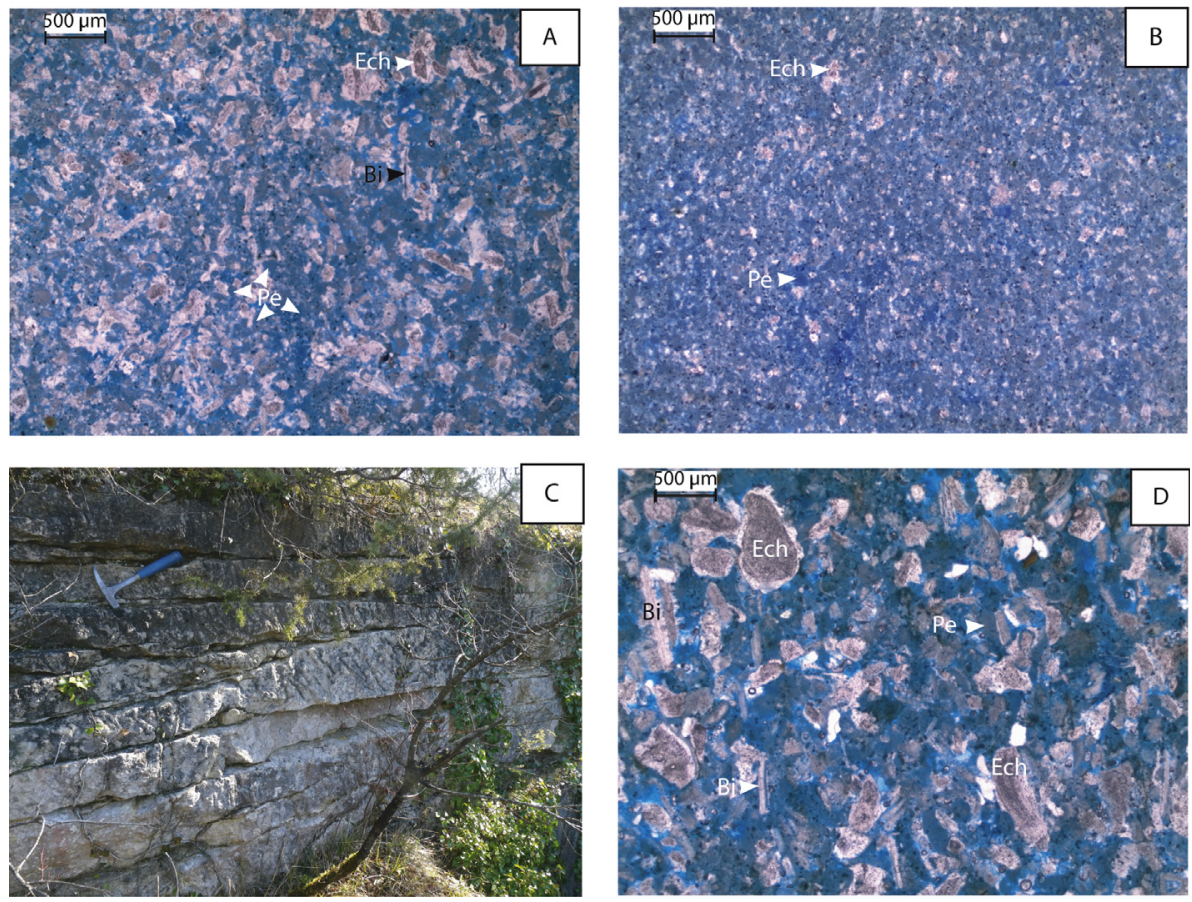

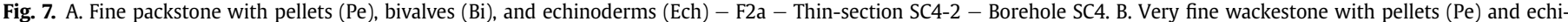

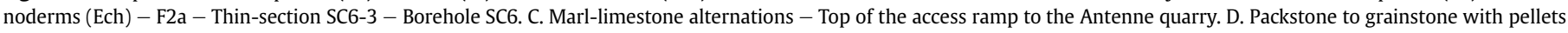
$(\mathrm{Pe})$, bivalves $(\mathrm{Bi})$, and echinoderms $(\mathrm{Ech})-\mathrm{F} 2 \mathrm{~b}-$ Thin section Pi85 - Picot quarry. 

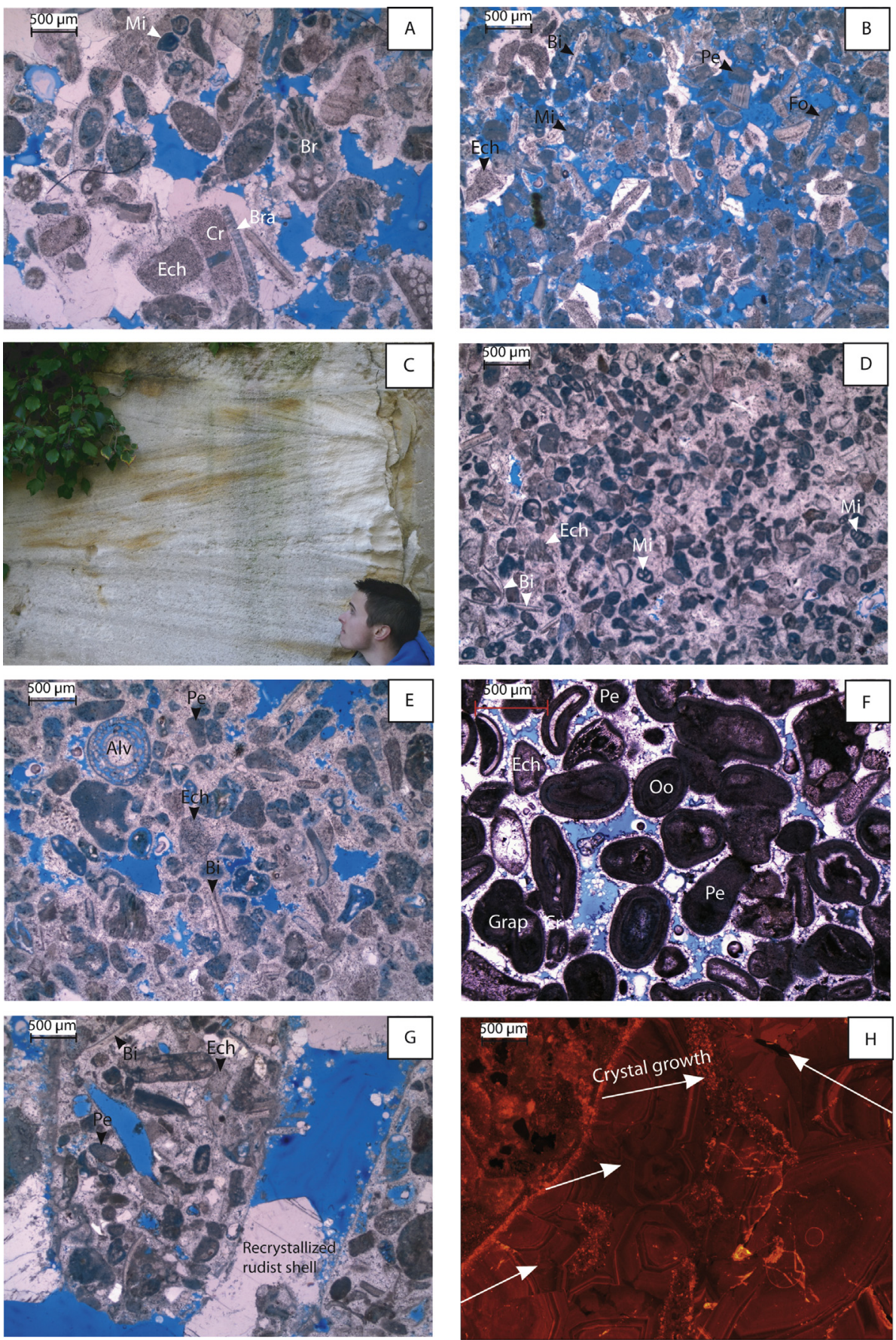

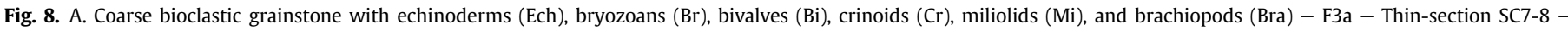

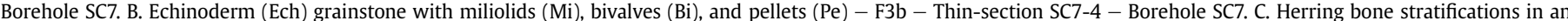

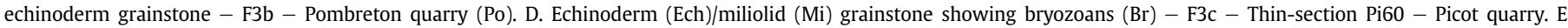

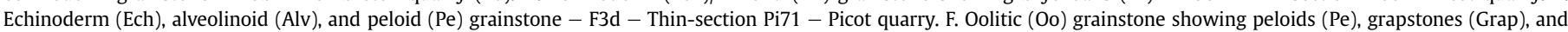

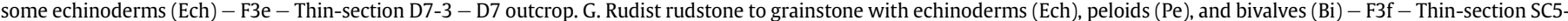
5 - Borehole SC5. H. Blocky calcite in cathodoluminescence.

wackestones/packstones rich in echinoderms, pellets, and bivalves (facies F2a). Mudstone facies rich in bivalves vertically followed by marl deposits several meters thick form the transgressive systems tract. The maximum flooding surface is in the marls at a depth of $34 \mathrm{~m}$ in the composite log of SC5 and SC6 boreholes (Figs. 5A and 10). The regressive systems tract is composed of mudstone with bivalves (facies F1c) and wackestone/packstone (facies F2a). The facies model is represented by lower offshore facies (mudstone, marls, and clays: facies F1c, F1b, and F1a) and upper offshore facies (wackestone to packstone, facies F2a) deposited along a gently dipping ramp (Fig. 11B). The top of the regressive systems tract of the $C_{C}$ sequence is characterized by a $90 \mathrm{~cm}$-thick lignite layer observed at Picot quarry (Fig. 10). This sequence boundary is a subaerial unconformity. The Cc sequence is characterized by a carbonate demise observable in the three logs where it is exposed (D7 road outcrop, composite log of the SC5 and SC6 boreholes, 

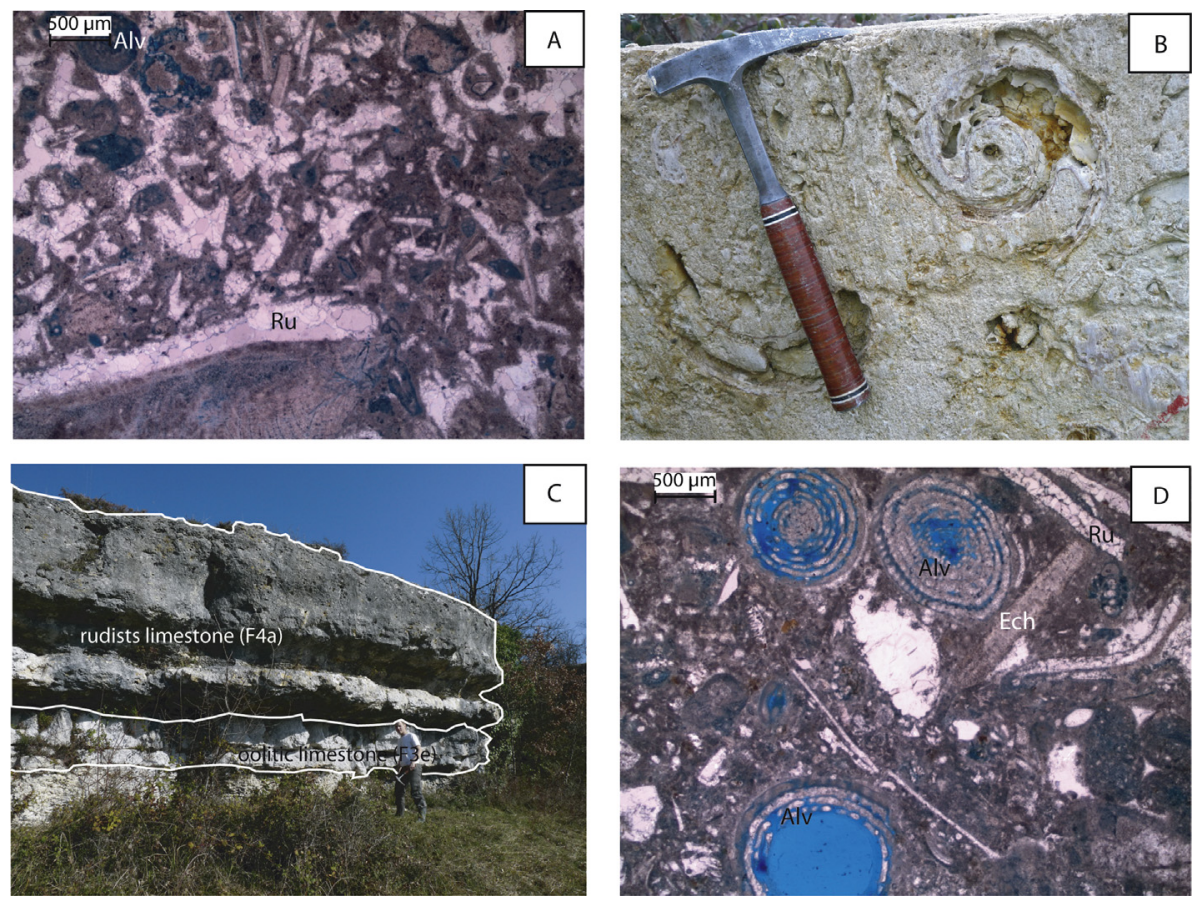

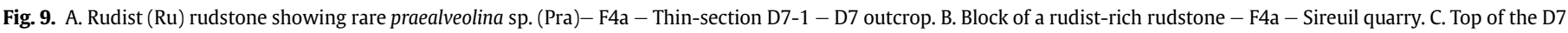
outcrop. D. Rudist $(\mathrm{Ru})$ and alveolinoids (Alv) rudstone with rare echinoderms (Ech) - F4b - Thin-section D7-5 - D7 outcrop.

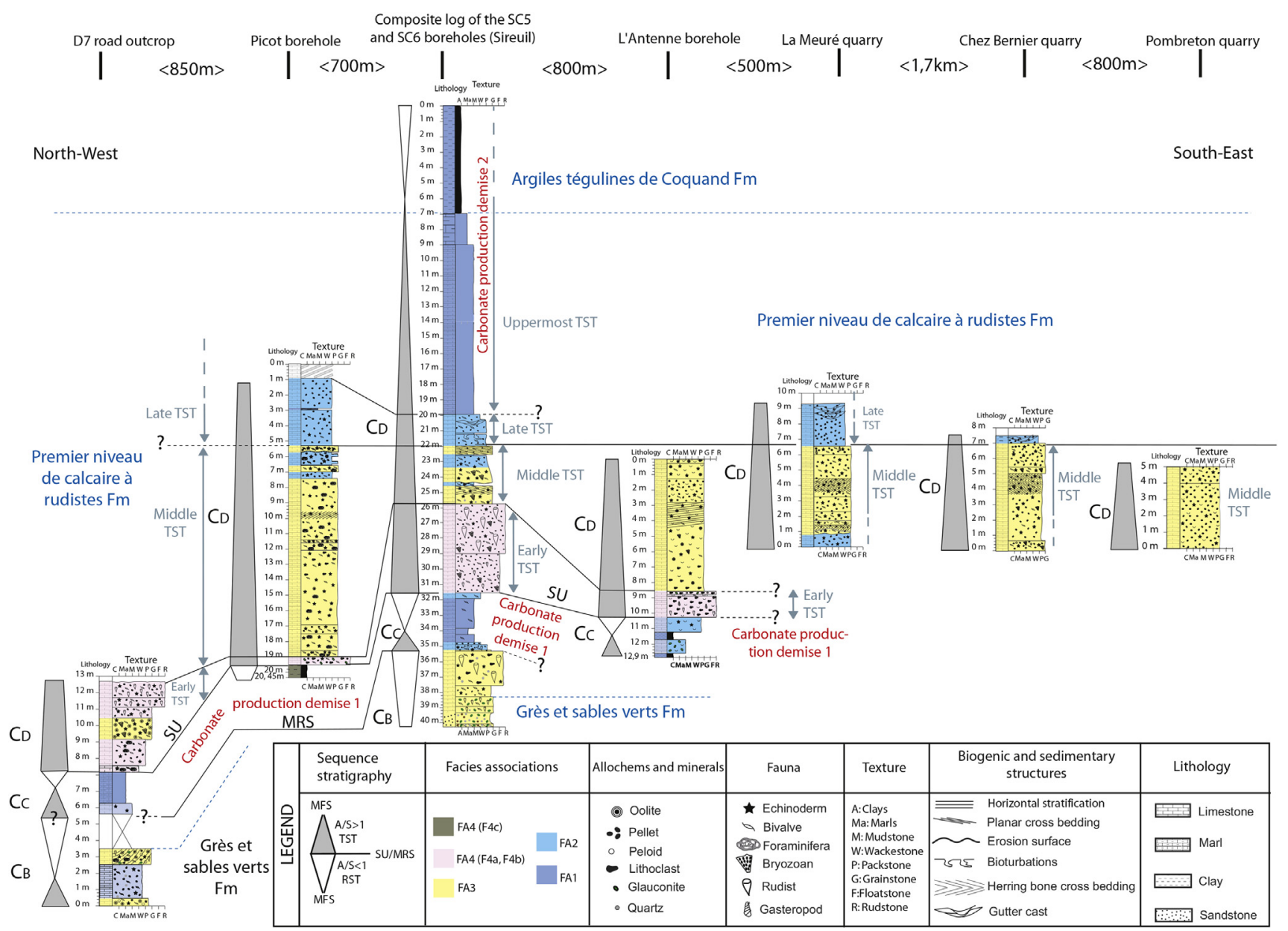

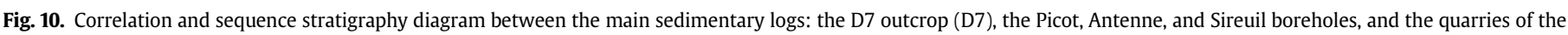
La Meuré, Chez Bernier, and Pombreton. 


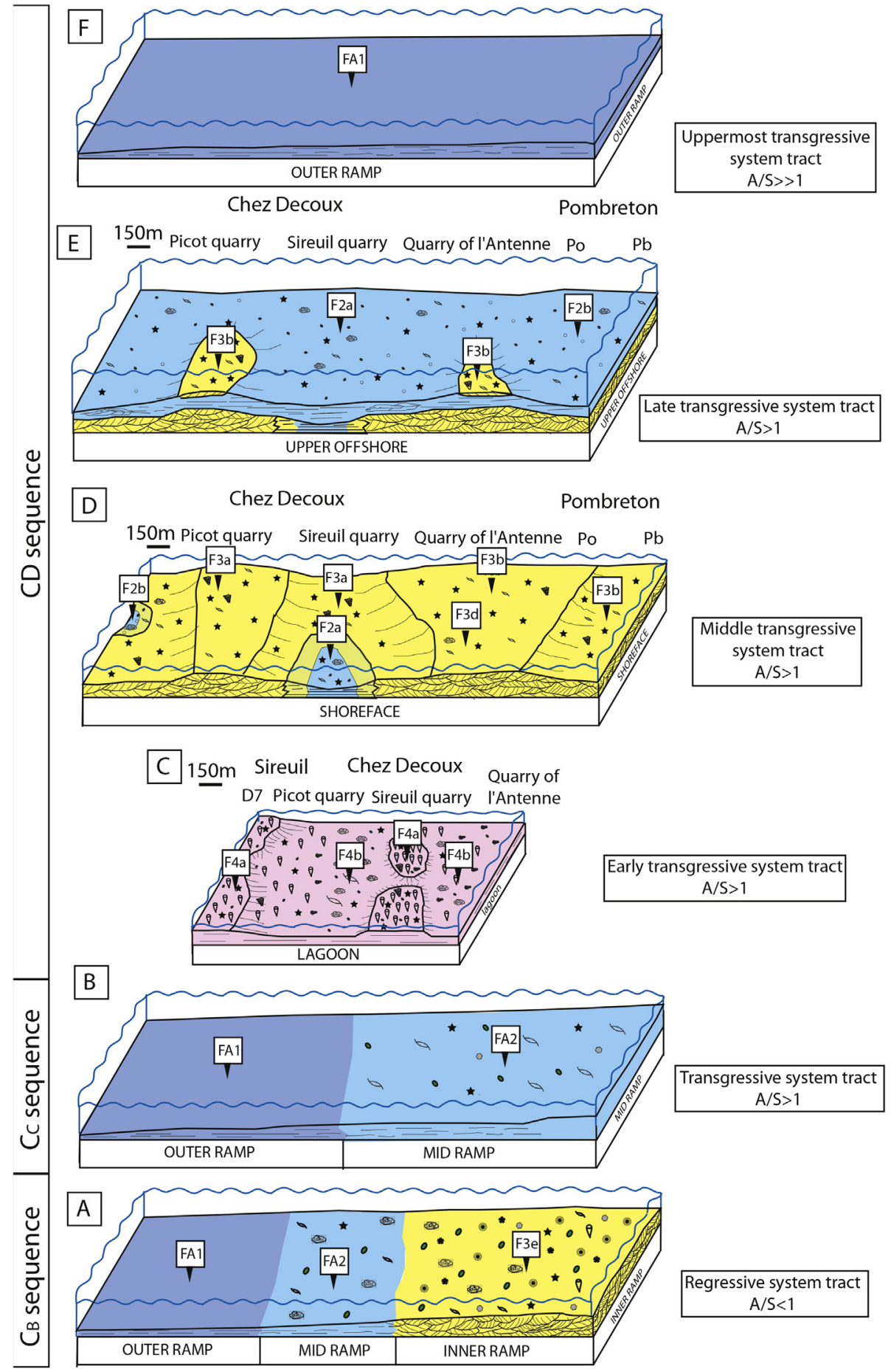

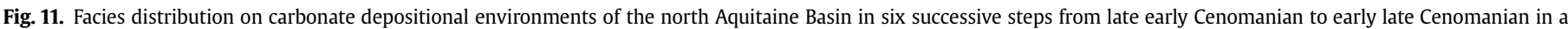

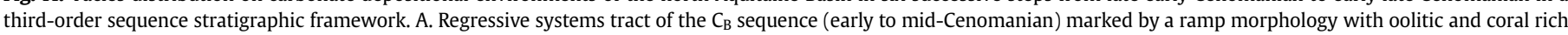

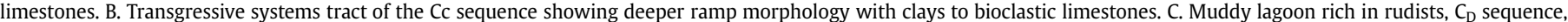

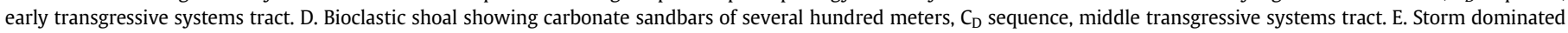

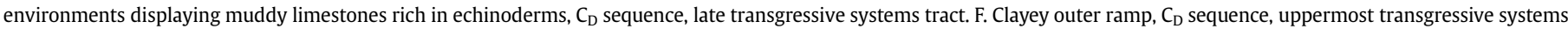
tract.

Antenne borehole), with the occurrence of marls (F1b) and clays (F1a); (Figs. 10 and 5A).

\subsubsection{The $C_{D}$ sequence (mid to late Cenomanian)}

The transgressive systems tract of the $C_{D}$ sequence contains all the facies associations, from the lignite layer (facies F4c) at the base to the FA1 facies association at the top (Figs. 5A and 10), forming 25-m-thick carbonate deposits. The early transgressive systems tract comprises facies from the FA4 facies association composed of micritic rudstones rich in rudists and foraminifera (Figs. 5A and 10). These facies are present at the base of the sequence from west to east. The study area was occupied by a lagoon during this early 
sequence (Figs. 10 and 11C). The thickness of the rudist level varies substantially, from $5.5 \mathrm{~m}$ in the SC5 borehole to $50 \mathrm{~cm}$ in the Picot borehole (Fig. 10). This can be explained by local rudist-bioherms in the lagoon, causing high carbonate productivity (Fig. 11C). Rudist bioherms probably separated the open platform in the west of the study area from the protected lagoon rich in miliolids and Praealveolina in the east (facies F4b) (Platel, 1998).

An echinoderm grainstone facies (facies F3a to F3d) forms the middle transgressive systems tract with sigmoid and herring bone stratifications (Figs. 5A and 9). This level varies widely in thickness from $3 \mathrm{~m}$ in the composite borehole of Sireuil quarry (Fig. 5A) to $11 \mathrm{~m}$ in the Picot borehole, although they are only three hundred meters apart horizontally (Fig. 10). The great thickness variations are explained by carbonate sandbars several hundred meters wide (Facies F3a-d, Fig. 11D) in the Picot and the Antenne quarries (Fig. 10). Some sedimentary logs (La Meuré, Sireuil, and Picot boreholes) display $1 \mathrm{~m}$-thick bioclastic packstone (facies F2a-b) intercalated between bioclastic grainstone facies (F3a-d). This could be explained by protected hollows below the fair-weather wave base (Fig. 11D). The top of the sandbars was affected by waves or tides, as indicated by cross-bedding stratification in the Sireuil, Chez Bernier, and La Meuré quarries (Figs. 10 and 11D). The top of the echinoderms grainstone facies is locally characterized by the occurrence of one or several hardgrounds. These hardgrounds, displaying abundant isopachous bladed early cement, are local and not referenced by Francis (1984).

In the late transgressive systems tract echinoderm/pellet wackestones to packstones tens of meters thick alternate with thin marly beds (facies F2a and F2b; Figs. 5A and 10). The local presence of echinoderm grainstone patches (facies F3a and F3b) intercalated between the micritic limestones reveals the existence of a topographic high affected by shoreface environments (Figs. 5A and 11E). The development of these shallow environments was probably favored by the paleorelief of the sandbars deposited during the middle part of the transgressive systems tract.

The uppermost part of the transgressive systems tract is composed of (1) beige mudstones with bivalves (facies F1c), (2) marls (facies F1b), and (3) clays (facies F1a, Fig. 9A) from $-19.7 \mathrm{~m}$ to $0 \mathrm{~m}$ in the composite Sireuil log (Fig. 5A). The paleoenvironment was an outer ramp with very fine clayey facies deposited below the storm wave base (Fig. 11F). The maximum flooding surface of the $C_{D}$ sequence is located in the upper Cenomanian "Argiles tégulines de Coquand" Formation. Francis (1984) described a regionallydeveloped hardground at the top of the "Premier niveau de calcaires à rudistes" Formation (lithostratigraphic unit C, Moreau, 1993, Figs. 3 and 5A). This hardground is relatively well expressed in core SC6 (Fig. 5A). In the synthetic sedimentological log of SC5 and SC6 boreholes (Fig. 5A), the depositional environments mark a progressive deepening from the base to the top of the $C_{C}$ sequence, with facies evolving from shallow carbonates (facies F3a to F3d) to upper offshore mudstone (facies F1c) and finally to lower offshore clays (facies F1a). The top surface of the mudstone facies appears sharp and bioturbated by vertical burrows. This surface between the "Premier Niveau à Rudistes" Formation and the "Argiles tégulines de Coquand" Formation could correspond to a sudden sea level rise before the maximum flooding surface. No early cementation evidence is found but this surface could correspond to a minor sedimentary gap as suggested by Francis (1984).

\subsection{Geochemistry}

Forty-two $\delta^{18} \mathrm{O}$ and $\delta^{13} \mathrm{C}$ values are available along the sedimentary section (Table 2, Fig. 12). Thirty-three were measured on the micrite matrix in mud-supported facies, four in well-preserved rudists, and five within poorly cemented grainstone samples. The stable carbon isotope ratio varies between $-1.7 \%$ and $+3.7 \%$ with a mean value of $2.8 \%$.

At the base of the section, within the lower Cenomanian "Grès et Sables verts" Formation, the values rise by $+0.7 \%$ from $2.1 \%$ o $(-38.5 \mathrm{~m})$ to $2.8 \%$ o ( $-37.4 \mathrm{~m}$; Fig. 12$)$. From $-37.4 \mathrm{~m}$ to $-22.2 \mathrm{~m}$, values fluctuate mostly between $2.4 \%$ and $2.8 \%$. This plateau features two maxima at $-33.2 \mathrm{~m}(3.3 \% 0)$ and $-22.2 \mathrm{~m}(3 \% 0)$ (Fig. 12). From $-22.2 \mathrm{~m}$ to $-20.2 \mathrm{~m}, \delta^{13} \mathrm{C}$ values decline significantly by about $1 \%$ (Fig. 12). This fall is followed by a rapid $+1.7 \%$ rise from $-20.2 m$ to $-19.3 m$. From $-19.3 m$ to $-6.3 m$, the values form another plateau with $\delta^{13} \mathrm{C}$ fluctuating between $3.3 \%$ and $3.7 \%$. From $-6.3 \mathrm{~m}$ to $-1.3 \mathrm{~m}$, the values decline steeply to $-1.7 \%$ o (Fig. 12).

The stable oxygen isotope ratio varies between $-5 \%$ and $-1.7 \%$ o with a mean value of $-3.5 \%$ (Fig. 12). The lower part of the depositional succession, from $-38.5 \mathrm{~m}$ to $-35.8 \mathrm{~m}$, displays a slow decline from $-3.5 \%$ to $-4.5 \%$. This trend is followed by a peak at $-33.2 \mathrm{~m}(-2.5 \%)$ (Fig. 12). From $-32.2 \mathrm{~m}$ to $-20.2 \mathrm{~m}$, values mainly fluctuate between $-4 \%$ and $-5 \%$. This plateau is punctuated only by a very high value of $-2.7 \%$ o (Fig. 12). From $-20.2 \mathrm{~m}$ to $-5.2 \mathrm{~m}$, the data show a progressive increase from $-5 \%$ to $-2.2 \%$. The values end with a fall to $-3.3 \%$ (Fig. 12).

Thirty nine measurements were made in well-preserved rudists $(\mathrm{n}=4)$ and in blocky calcite cements $(\mathrm{n}=35$, Fig. $8 \mathrm{H})$ from geodes in order to evaluate the initial isotopic composition of the sea water and the potential diagenetic effect on isotopic values from the micrite matrix (Table 2, Fig. 13). The preservation of the rudist shells was estimated performing catholuminescence microscopy. Wellpreserved rudist shells are non-luminescent under cathodoluminescence microscopy, while recrystallized rudist shells are filled by blocky calcite (sparite), and have an orange luminescence. Stable oxygen isotope values display considerable variability, from $-7.5 \%$ in blocky calcites to $-1.7 \%$ in well-preserved rudist shells. The blocky calcites have the lowest $\delta^{18} \mathrm{O}$ values and the greatest variability of the $\delta^{18} \mathrm{O}$ data set from $-7.5 \%$ to $-3.7 \%$. The micrite samples have higher $\delta^{18} \mathrm{O}$ values than the blocky calcite and moderate variability from $-5.0 \%$ to $-2.2 \%$. The rudist $\delta^{18} \mathrm{O}$ values are the highest from the data set from $-2.8 \%$ to $-1.7 \%$. The poorly cemented grainstone $\delta^{18} \mathrm{O}$ values range from $-4.5 \%$ to $-3.5 \%$.

The $\delta^{13} \mathrm{C}$ values do not display any clear variations with sample type, in contrast to $\delta^{18} \mathrm{O}$ data. The $\delta^{13} \mathrm{C}$ values in micrite range from $1.9 \%$ to $3.7 \%$, except for two micrite samples from the uppermost section (Fig. 12). However, $\delta^{13} \mathrm{C}$ variability in blocky calcite, from $2.4 \%$ o to $3.4 \%$ (except for one sample with a value of $1.9 \%$ ), is slightly lower than the variability in the micrite samples (Fig. 13). The rudists $\delta^{13} \mathrm{C}$ values range between $2.4 \%$ and $2.9 \%$.

\section{Discussion}

\section{1. $\delta^{18} \mathrm{O}$ vs $\delta^{13} \mathrm{C}$ signals: diagenetic influence}

In order to evaluate the possible $\delta^{18} \mathrm{O}$ and $\delta^{13} \mathrm{C}$ diagenetic signals, we measured the carbonate cements in recrystallized rudists or geodes directly (Fig. $8 \mathrm{H}$ ). We identified a well-defined $\delta^{18} \mathrm{O}$ diagenetic domain from $-7.5 \%$ to $-4.5 \%$ (Fig. 13). Four wellpreserved rudist shells display the initial $\delta^{18} \mathrm{O}$ signal of carbonate between $-2.8 \%$ and $-1.7 \%$ (Fig. 13). For the $\delta^{13} \mathrm{C}$, most diagenetic cement values are in the range of $\delta^{13} \mathrm{C}$ rudist values from $2.4 \%$ to $2.9 \%$. In order to estimate the possible parent fluid compositions from the $\delta^{18} \mathrm{O}$ values, we need to assess the thermal evolution of the study area. The lowest temperature was the sea water temperature during the Cenomanian. This stage was the warmest of the Cretaceous period with sea water temperatures reaching $25-30{ }^{\circ} \mathrm{C}$ (Pucéat et al., 2003). The maximum temperature of the Cenomanian rocks was reached during maximum burial, at the end of 
Table 2

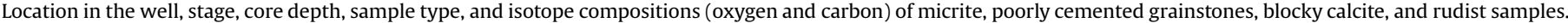

\begin{tabular}{|c|c|c|c|c|c|c|}
\hline Sample name & Well/outcrop name & Stage & Core depth (m) & Sample type & $\delta^{13} \mathrm{C}(\%$. PDB $)$ & $\delta^{18} \mathrm{O}(\% . \mathrm{PDB})$ \\
\hline SC6-7 & SC6 & late Cenomanian & 1.3 & micrite & -1.699 & -3.281 \\
\hline SC6-8 & SC6 & late Cenomanian & 2.3 & micrite & 0.381 & -3.446 \\
\hline SC6-9 & SC6 & late Cenomanian & 3.3 & micrite & 1.912 & -3.184 \\
\hline SC6-10 & SC6 & late Cenomanian & 4.3 & micrite & 2.556 & -3.09 \\
\hline SC6-11 & SC6 & late Cenomanian & 5.3 & micrite & 2.927 & -2.164 \\
\hline SC6-12 & SC6 & late Cenomanian & 6.3 & micrite & 3.296 & -2.281 \\
\hline SC6-13 & SC6 & late Cenomanian & 7.3 & micrite & 3.514 & -2.441 \\
\hline SC6-15 & SC6 & late Cenomanian & 9.3 & micrite & 3.613 & -2.483 \\
\hline SC6-16 & SC6 & late Cenomanian & 10.2 & micrite & 3.382 & -2.885 \\
\hline SC6-17 & SC6 & late Cenomanian & 11.3 & micrite & 3.349 & -3.839 \\
\hline SC6-18 & SC6 & late Cenomanian & 12.3 & micrite & 3.728 & -2.843 \\
\hline SC6-19 & SC6 & middle Cenomanian & 13.3 & micrite & 3.621 & -2.953 \\
\hline SC6-20 & SC6 & middle Cenomanian & 14.3 & micrite & 3.455 & -3.394 \\
\hline SC6-21 & SC6 & middle Cenomanian & 15.2 & micrite & 3.577 & -3.102 \\
\hline SC6-22 & SC6 & middle Cenomanian & 16.2 & micrite & 3.546 & -3.391 \\
\hline SC6-23 & SC6 & middle Cenomanian & 17.3 & micrite & 3.363 & -3.597 \\
\hline SC6-24 & SC6 & middle Cenomanian & 18.3 & micrite & 3.323 & -4.131 \\
\hline SC6-25 & SC6 & middle Cenomanian & 19.3 & micrite & 3.399 & -3.675 \\
\hline SC6-26 & SC6 & middle Cenomanian & 20.2 & micrite & 1.968 & -5.002 \\
\hline SC6-27 & SC6 & middle Cenomanian & 21.3 & micrite & 2.457 & -4.826 \\
\hline SC6-28 & SC6 & middle Cenomanian & 22.2 & poorly cemented grainstone & 2.968 & -4.239 \\
\hline SC6-29 & SC6 & middle Cenomanian & 23.3 & micrite & 2.821 & -4.188 \\
\hline SC6-30 & SC6 & middle Cenomanian & 24.5 & micrite & 2.683 & -3.975 \\
\hline SC6-31 & SC6 & middle Cenomanian & 25.3 & poorly cemented grainstone & 2.395 & -4.462 \\
\hline SC6-1 & SC6 & middle Cenomanian & 26 & blocky calcite & 2.97 & -6.68 \\
\hline SC5-8 & SC5 & middle Cenomanian & 0.7 & micrite & 2.577 & -2.657 \\
\hline SC5-9 & SC5 & middle Cenomanian & 1.7 & micrite & 2.656 & -4.201 \\
\hline SC5-4 & $\mathrm{SC} 5$ & middle Cenomanian & 2.1 & blocky calcite & 3.02 & -7.16 \\
\hline SC5-4 & SC5 & middle Cenomanian & 2.1 & blocky calcite & 2.81 & -7.51 \\
\hline SC5-4 & SC5 & middle Cenomanian & 2.1 & blocky calcite & 3.01 & -7.15 \\
\hline SC5-4 & SC5 & middle Cenomanian & 2.1 & blocky calcite & 3.15 & -6.33 \\
\hline SC5-4 & SC5 & middle Cenomanian & 2.1 & blocky calcite & 2.66 & -5.00 \\
\hline SC5-4 & SC5 & middle Cenomanian & 2.1 & blocky calcite & 2.52 & -4.49 \\
\hline SC5-10 & SC5 & middle Cenomanian & 2.7 & micrite & 2.911 & -4.372 \\
\hline SC5-11 & SC5 & middle Cenomanian & 3.6 & micrite & 2.855 & -4.232 \\
\hline SC5-12 & SC5 & middle Cenomanian & 4.6 & micrite & 2.912 & -4.805 \\
\hline SC5-13 & SC5 & middle Cenomanian & 5.7 & micrite & 2.761 & -4.242 \\
\hline SC5-14 & $\mathrm{SC} 5$ & middle Cenomanian & 6.7 & micrite & 2.576 & -4.312 \\
\hline SC5-15 & SC5 & middle Cenomanian & 7.7 & micrite & 3.313 & -2.5 \\
\hline SC5-16 & SC5 & middle Cenomanian & 8.5 & micrite & 2.89 & -2.553 \\
\hline SC5-17 & SC5 & middle Cenomanian & 9.5 & micrite & 2.865 & -3.086 \\
\hline SC5-3A & SC5 & middle Cenomanian & 9.8 & rudist & 2.39 & -2.77 \\
\hline SC5-3A & SC5 & middle Cenomanian & 9.8 & rudist & 2.41 & -2.66 \\
\hline SC5-3A & SC5 & middle Cenomanian & 9.8 & blocky calcite & 3.11 & -6.19 \\
\hline SC5-3A & SC5 & middle Cenomanian & 9.8 & blocky calcite & 3.14 & -6.93 \\
\hline SC5-3A & $\mathrm{SC} 5$ & middle Cenomanian & 9.8 & blocky calcite & 3.20 & -6.46 \\
\hline SC5-3A & SC5 & middle Cenomanian & 9.8 & blocky calcite & 2.99 & -6.28 \\
\hline SC5-3A & SC5 & middle Cenomanian & 9.8 & blocky calcite & 3.28 & -6.63 \\
\hline SC5-3A & SC5 & middle Cenomanian & 9.8 & blocky calcite & 3.14 & -6.79 \\
\hline SC5-3A & SC5 & middle Cenomanian & 9.8 & blocky calcite & 2.94 & -7.02 \\
\hline SC5-3B & SC5 & middle Cenomanian & 9.8 & rudist & 2.85 & -1.72 \\
\hline SC5-3B & SC5 & middle Cenomanian & 9.8 & blocky calcite & 2.75 & -5.00 \\
\hline SC5-3B & SC5 & middle Cenomanian & 9.8 & blocky calcite & 3.00 & -5.22 \\
\hline SC5-3B & SC5 & middle Cenomanian & 9.8 & blocky calcite & 2.94 & -7.38 \\
\hline SC5-3C & SC5 & middle Cenomanian & 9.8 & rudist & 2.37 & -2.51 \\
\hline SC5-3C & SC5 & middle Cenomanian & 9.8 & blocky calcite & 2.41 & -3.66 \\
\hline SC5-3C & SC5 & middle Cenomanian & 9.8 & blocky calcite & 2.56 & -7.52 \\
\hline SC5-3C & SC5 & middle Cenomanian & 9.8 & blocky calcite & 3.37 & -6.66 \\
\hline SC5-3C & SC5 & middle Cenomanian & 9.8 & blocky calcite & 2.82 & -5.17 \\
\hline SC5-18 & SC5 & middle Cenomanian & 10.4 & poorly cemented grainstone & 2.725 & -4.474 \\
\hline SC5-19 & SC5 & middle Cenomanian & 11.3 & poorly cemented grainstone & 2.76 & -4.191 \\
\hline SC5-5 & SC5 & middle Cenomanian & 11.4 & blocky calcite & 2.66 & -5.40 \\
\hline SC5-5 & SC5 & middle Cenomanian & 11.4 & blocky calcite & 1.82 & -5.99 \\
\hline SC5-6 & SC5 & middle Cenomanian & 11.6 & blocky calcite & 2.90 & -6.49 \\
\hline SC5-6 & SC5 & middle Cenomanian & 11.6 & blocky calcite & 2.49 & -7.38 \\
\hline SC5-6 & SC5 & middle Cenomanian & 11.6 & blocky calcite & 2.91 & -5.60 \\
\hline SC5-6 & SC5 & middle Cenomanian & 11.6 & blocky calcite & 2.72 & -5.35 \\
\hline SC5-6 & SC5 & middle Cenomanian & 11.6 & blocky calcite & 3.05 & -7.08 \\
\hline SC5-6 & SC5 & middle Cenomanian & 11.6 & blocky calcite & 2.92 & -6.37 \\
\hline SC5-6 & SC5 & middle Cenomanian & 11.6 & blocky calcite & 2.98 & -5.99 \\
\hline SC5-6 & SC5 & middle Cenomanian & 11.6 & blocky calcite & 2.91 & -5.29 \\
\hline SC5-6 & SC5 & middle Cenomanian & 11.6 & blocky calcite & 2.75 & -4.87 \\
\hline SC5-6 & SC5 & middle Cenomanian & 11.6 & blocky calcite & 2.99 & -6.83 \\
\hline SC5-6 & SC5 & middle Cenomanian & 11.6 & blocky calcite & 2.66 & -5.18 \\
\hline
\end{tabular}


Table 2 (continued)

\begin{tabular}{|c|c|c|c|c|c|c|}
\hline Sample name & Well/outcrop name & Stage & Core depth (m) & Sample type & $\delta^{13} \mathrm{C}(\%$. PDB $)$ & $\delta^{18} \mathrm{O}(\% . \mathrm{PDB})$ \\
\hline SC5-20 & SC5 & middle Cenomanian & 12.5 & micrite & 2.842 & -3.698 \\
\hline SC5-21 & SC5 & early Cenomanian & 13.5 & poorly cemented grainstone & 2.143 & -3.481 \\
\hline D7-5 & D7 road & middle Cenomanian & outcrop & blocky calcite & 3.03 & -7.22 \\
\hline
\end{tabular}

the Cretaceous, corresponding to 550 m-thick deposits above the Cenomanian carbonates (Platel, 1996). Assuming a thermal gradient of $30{ }^{\circ} \mathrm{C} / \mathrm{km}$ and a surface temperature of $20{ }^{\circ} \mathrm{C}$, the temperature reached during the maximum burial was about $40^{\circ} \mathrm{C}$. From the early Paleocene to the present, the Cenomanian rocks have been exhumed (Biteau et al., 2006) and so temperatures have fallen. Considering a temperature range of $25-40{ }^{\circ} \mathrm{C}$ during burial, the pore fluid composition of blocky calcite cements, whose $\delta^{18} \mathrm{O}$ values vary from $-7.5 \%$ to $-4.5 \%$, ranges from $-5 \%$ V-SMOW to $+1 \%$ V-SMOW according to the calcite-water fractionation equation of Kim and O'Neil (1997). Cenomanian sea water heated with increasing burial implies temperatures of $50-60{ }^{\circ} \mathrm{C}$ for the lowest $\delta^{18} \mathrm{O}$ values of calcite ( -6 to $-7.5 \%$; Fig. 13 ), which is unrealistic judging the shallow burial history of the north Aquitaine platform. Meteoric burial diagenesis originated blocky calcite cements (Fig. $8 \mathrm{H}$ ) in intragranular spaces, in geodes and was responsible for the recrystallization of some rudist shells. Meteoric diagenetic processes change the $\delta^{18} \mathrm{O}$ signal in well cemented grainstone facies. Three micritic matrix $\delta^{18} \mathrm{O}$ values ranging from $-5 \%$ to $-4.8 \%$ are in the domain of possible meteoric

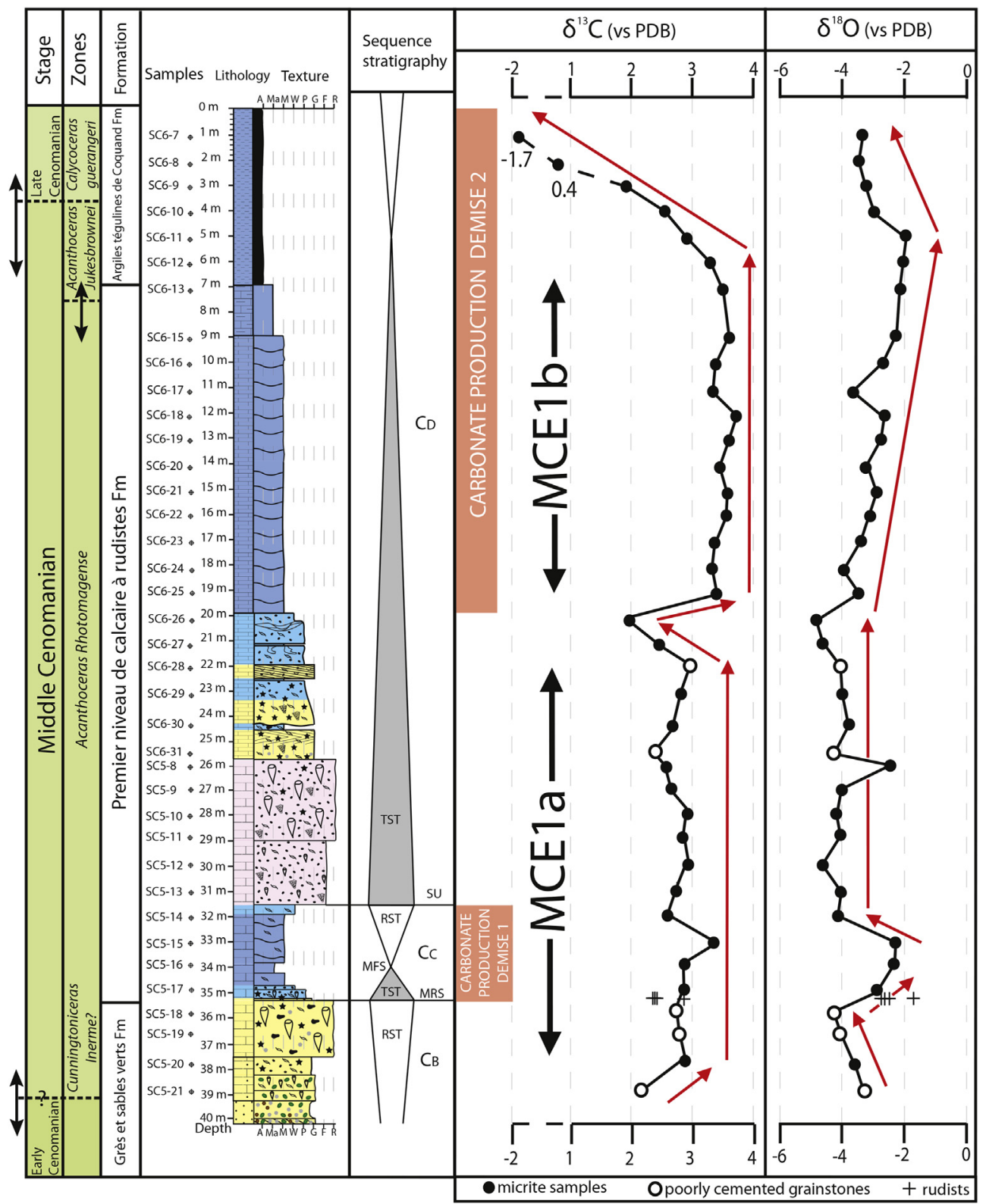

Fig. 12. Evolution of the $\delta^{18} \mathrm{O}$ and $\delta^{13} \mathrm{C}$ values during the Cenomanian compared to the composite sedimentological log (SC6 and SC5 boreholes) and sequence stratigraphy. 


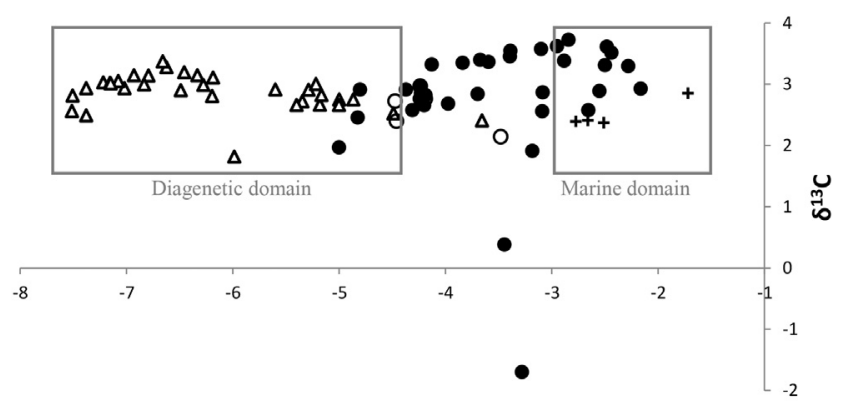

$\delta^{18} \mathrm{O}$

- Micrite + Rudist $\Delta$ Blocky calcite OPoorly cemented grainstone

Fig. 13. $\delta^{18} \mathrm{O}$ and $\delta^{13} \mathrm{C}$ composition of 33 micrites, 35 blocky calcites, 4 rudists, and 5 poorly cemented grainstones.

diagenesis and may have been affected by meteoric diagenetic microcements (Fig. 13). One poorly cemented grainstone $\delta^{18} \mathrm{O}$ value of $-4.5 \%$ could have been affected by meteoric diagenesis. We will avoid interpreting the entire $\delta^{18} \mathrm{O}$ micritic matrix values and poorly cemented grainstone data set in terms of the paleoenvironment. By contrast, the blocky calcite cements (Fig. $8 \mathrm{H}$ ) cannot be differentiated by their $\delta^{13} \mathrm{C}$ compositions, suggesting that the meteoric fluids were buffered with the surrounding marine carbonates. Carbon isotope data can therefore be regarded as reflecting disturbances of the initial carbon cycle.

\subsection{The Mid-Cenomanian Event: review and $\delta^{13} \mathrm{C}$ inter basin correlation}

The Mid-Cenomanian Event (MCE1) was a carbon isotope excursion involving two closely spaced positive peaks, MCE1a and MCE1b. MCE1 is characterized by the occurrence of black shale deposits in ODP Leg 207 only (tropical Atlantic Ocean, Demerara Rise; Friedrich et al., 2009) and so is not considered as an OAE. MCE1 also differs from OAEs by its lower intensity of about $+1 \%$ shift compared to about $+3 \%$ shift for OAE2 (Gertsch et al., 2010). All previous studies have identified MCE1 in clayey basin deposits, in deep carbonate (marl-limestone alternations) deposits of hemipelagic basins (Fig. 14), or in terrestrial organic matter (Uramoto et al., 2007).

In shallow carbonate deposits of the Aquitaine platform, MCE1a is detected and corresponds to a plateau at about 2.8\%o (Figs. 12 and 14). This plateau displays a sharp rise around the early/midCenomanian transition of about $+0.6 \%$ from $2.2 \%$ to $2.8 \%$. The maximum amplitude from $2.2 \%$ to $3.3 \%$ is $+1.1 \%$. The end of this plateau corresponds to a rapid fall from $3.0 \%$ to $2.0 \%$ (Figs. 12 and 14). The north Aquitaine platform section shows in its upper part an extended plateau at about $3.5 \%$ characterized by a $+1.7 \%$ excursion from $2.0 \%$ to $3.7 \%$ (Figs. 12 and 14). After the end of this second plateau, $\delta^{13} \mathrm{C}$ values fall from $3.7 \%$ to $-1.7 \%$ at the beginning of the late Cenomanian (Figs. 12 and 14). This sudden fall at the end of the MCE1b also occurs in the $\delta^{13} \mathrm{C}$ values of the Azaoul section, which display a rapid decrease from $1.9 \%$ to $-1 \%$ (Fig. 12). The diagenesis influence is not suggested by the authors to explain this profile (Gertsch et al., 2010). In the northern Aquitaine platform, there is no noteworthy correlation between the $\delta^{18} \mathrm{O}$ and the $\delta^{13} \mathrm{C}$ values at the middle-late Cenomanian boundary (Fig. 12). The $\delta^{18} \mathrm{O}$ data display a small fall from $-2.2 \%$ to $-3.1 \%$ between $-5.3 \mathrm{~m}$ and $-4.3 \mathrm{~m}$ and are stable from $-4.3 \mathrm{~m}$ to $-1.3 \mathrm{~m}$ (Fig. 12). In the "Argiles tégulines de Coquand" Formation, the $\delta^{18} \mathrm{O}$ values are not include in the diagenetic domain (Fig. 12). The low $\delta^{13} \mathrm{C}$ values are so not controlled by meteoric diagenesis. The last two $\delta^{13} \mathrm{C}$ values at $-2.3 \mathrm{~m}$ and $-1.3 \mathrm{~m}$ are very low $(0.4 \%$ and $-1.7 \%$, Figs. 12 and 13 ) and can reflect early diagenesis under organic matter influence (Lavastre et al., 2011; Pellenard et al., 2014). However, the rapid fall from $3.7 \%$ to $1.9 \%$ in the "Argiles tégulines de Coquand" Formation can be interpreted as reflecting the global carbon cycle signal.

The two plateaus correspond to MCE1a and MCE1b, which are very well expressed in the $\delta^{13} \mathrm{C}$ correlation diagram from sections in England (Southerham and Folkestone) to Morocco (Azaoul, Fig. 14). The amplitude of the $\delta^{13} \mathrm{C}$ excursion varies widely in the different sections (Fig. 14). MCE1a and MCE1b amplitudes vary accordingly: (1) $+0.5 \%$ and $+0.6 \%$ for the Southerham section, (2) $+0.5 \%$ and $+0.9 \%$ for the Folkestone section, $(2)+0.5 \%$ and $+0.8 \%$ for the Cap Blanc-Nez section (Paris Basin, France), $(3)+0.6 \%$ and $+1.1 \%$ for the Blieux section (Vocontian Basin, France) and (4) $+2 \%$ and $+2 \%$ for the Azaoul section (Morocco). The highest $\delta^{13} \mathrm{C}$ excursion amplitude is registered in the ODP Leg 207 (tropical Atlantic Ocean, Demerara Rise; Friedrich et al., 2009), and is about $+4 \%$ for MCE1a and $+2.2 \%$ for MCE1b. In the Aquitaine platform, the MCE1a shift $(+1.1 \% 0)$ is better expressed than in the Cap Blanc-Nez and Blieux sections but lower than in the Azaoul and Demerara Rise sections. In the north Aquitaine shallow-marine carbonates, MCE1b is very well marked with $a+1.7 \%$ positive excursion, which is slightly lower than the MCE1b excursion in the Azaoul section. MCE1 is detected for the first time in shallowmarine carbonates and appears to be very well expressed. In the northern France and England basins, the $\delta^{13} \mathrm{C}$ data show a standard profile during the middle Cenomanian, with a characteristic double peak (MCE1a and MCE1b, Fig. 14). The amplitude of the $\delta^{13} \mathrm{C}$ values increase fluctuates between $0.5 \%$ and $0.6 \%$ for MCE1a and between $0.6 \%$ and $0.9 \%$ for MCE1b (Fig. 14). However in the southern basins, the $\delta^{13} \mathrm{C}$ values display slightly different profiles for the MCE1 (Fig. 14). In the Blieux section, the MCE1b is characterized by a $+1.1 \%$ excursion followed by a large plateau. A similar plateau also characterized the MCE1b in the northern Aquitaine platform (Fig. 14). In the Azaoul section, the MCE1a and MCE1b amplitude is about $+2 \%$, which is, like for the northern Aquitaine platform, significantly greater than for the northern France and England basins. This high amplitude might be characteristic of shallower records.

The carbon isotope composition $\left(\delta^{13} \mathrm{C}\right)$ of bulk carbonates, obtained from a transect of Holocene to early Miocene drilled sediments from the Great Bahamas Bank to the basin, exhibits anticorrelated trends of the $\delta^{13} \mathrm{C}$ curves between the basin and the platform (Swart and Eberli, 2006), making platform-to-basin isotopic correlation difficult. When a negative $\delta^{13} \mathrm{C}$ excursion is detected in shallow platform deposits, a positive $\delta^{13} \mathrm{C}$ excursion is recorded in pelagic sediments. The hypothesis advanced to explain this result was the diagenetic influence of early meteoric water due to subaerial emersion. In the Aquitaine platform, no evidence has been found of early meteoric diagenesis, such as meniscus cements, microstalactitic cements, or karstifications. Only meteoric diagenesis during burial responsible for blocky calcite cement development is documented. Our study displays similar trends between basin and shallow platform $\delta^{13} \mathrm{C}$ curves. This very well marked record of MCE1 allows us to discuss its effect on carbonate producers, facies distribution, and architecture.

\subsection{The Mid-Cenomanian Event: influence on shallow-marine carbonate producers and depositional geometry}

\subsubsection{Signification of facies associations in terms of nutrient conditions}

The early Cenomanian on the northern Aquitaine platform is marked by $5-20$ m-thick sandstones alternating with oolitic 


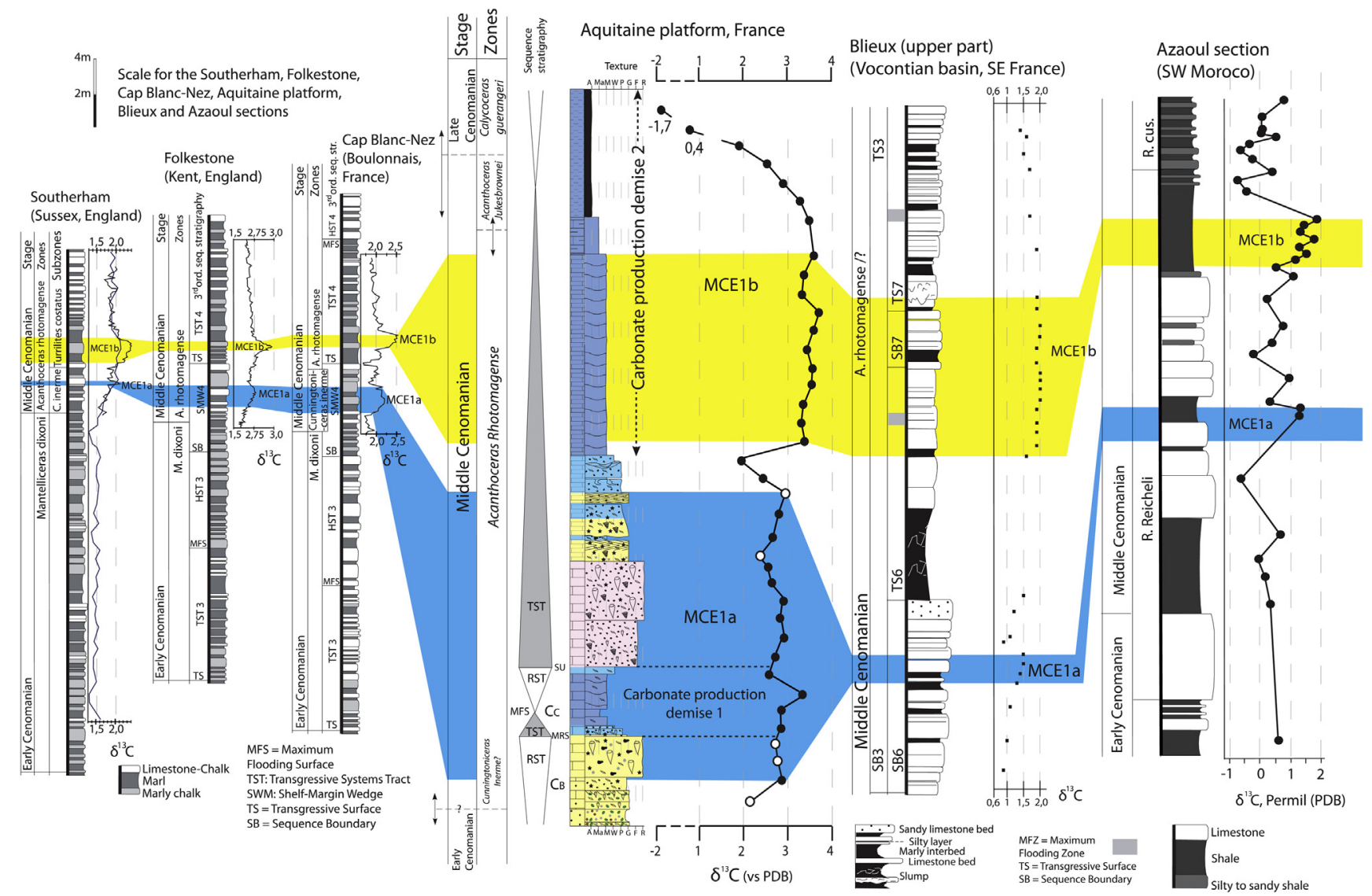

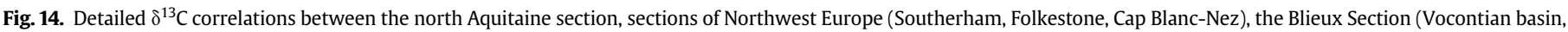

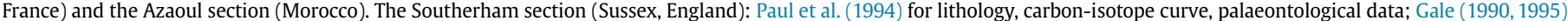

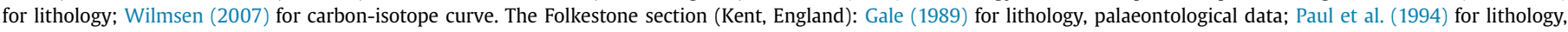

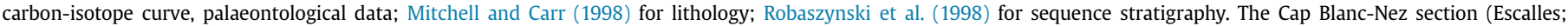

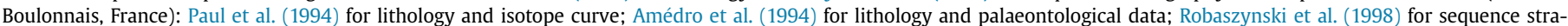

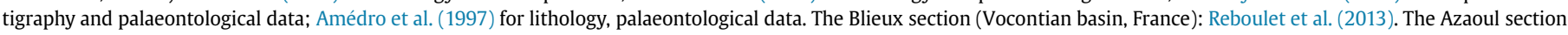
(Morocco): Gertsch et al. (2010); Kuhnt et al. (2009).

carbonate deposits (Moreau and Platel, 1982; Moreau, 1996). Only the upper part of these early Cenomanian limestones is described in this study. They are rich in ooids, coral fragments, peloids, intraclasts, or aggregates, which are the main carbonate producers with echinoderms, foraminifera, and rudists in minor proportions (facies F3e, Fig. 15). This grain association is called photozoan, marking warm sea water temperatures $\left(>22{ }^{\circ} \mathrm{C}\right)$ and oligotrophic conditions in a sub-tropical environment (James, 1997; Mutti and Hallock, 2003). Carbon isotopic values were normal at about $2 \%$ during the early Cenomanian (Fig. 15).

Middle Cenomanian limestones, deposited during the MCE1, display completely different carbonate grain associations that are composed mostly by echinoderms, brachiopods, bryozoans, and rudists in lower proportions (Fig. 15). This heterozoan grain association is typical of cool-water carbonates (James, 1997). However, Mutti and Hallock (2003) suggest that this grain association might occur in a sub-tropical environment when the nutrient gradient is high under mesotrophic to eutrophic conditions. As temperature during the Cenomanian was warm and relatively stable (Puceat et al., 2003), the facies change between early and midCenomanian can be related to nutrient increase, leading to increased planktonic biomass and reduced light penetration (James, 1997; Mutti and Hallock, 2003; Föllmi et al., 2006; Föllmi, 2012).

\subsubsection{Evolution of depositional sequences, facies, and geometry} during MCE1

The third-order depositional sequences $C_{B}, C_{C}$, and $C_{D}$ identified in the study area are well correlated with the eustatic chart for the European basins (Hardenbol et al., 1998) and with the sequences described by Robaszynski et al. (1998) in Sarthe. Robaszynski et al. (1998) identified three third-order sequences from the late early Cenomanian to the early late Cenomanian (sequences 3, 4 and 5). These sequences are comparable to the sequences $C_{B}, C_{C}$, and $C_{D}$ of the northern Aquitaine Basin.

The sequence boundary between $C_{B}$ and $C_{C}$ at the base of the middle Cenomanian is well-marked in the study area by a sudden facies change from lower offshore to shoreface environments (Fig. 12). This corresponds to a second-order sequence boundary at European scale. A single full third-order sequence $\left(C_{C}\right)$ is recorded in our study area for the mid-Cenomanian, as in the eustatic chart (Hardenbol et al., 1998). The upper boundary of the $C_{B}$ sequence is marked by a regionally-developed hardground, in northern Aquitaine and Sarthe (Francis, 1984). In our study the upper boundary of the $C_{B}$ sequence is characterized by the occurrence of glauconite, dissolution and an abundant early cementation. The early cements are isopachous with bladed crystals and formed in marine water environment (Purser, 1969; Durlet and Loreau, 1996; Brigaud et al., 2009). The upper boundary of the $C_{B}$ sequence does not display 


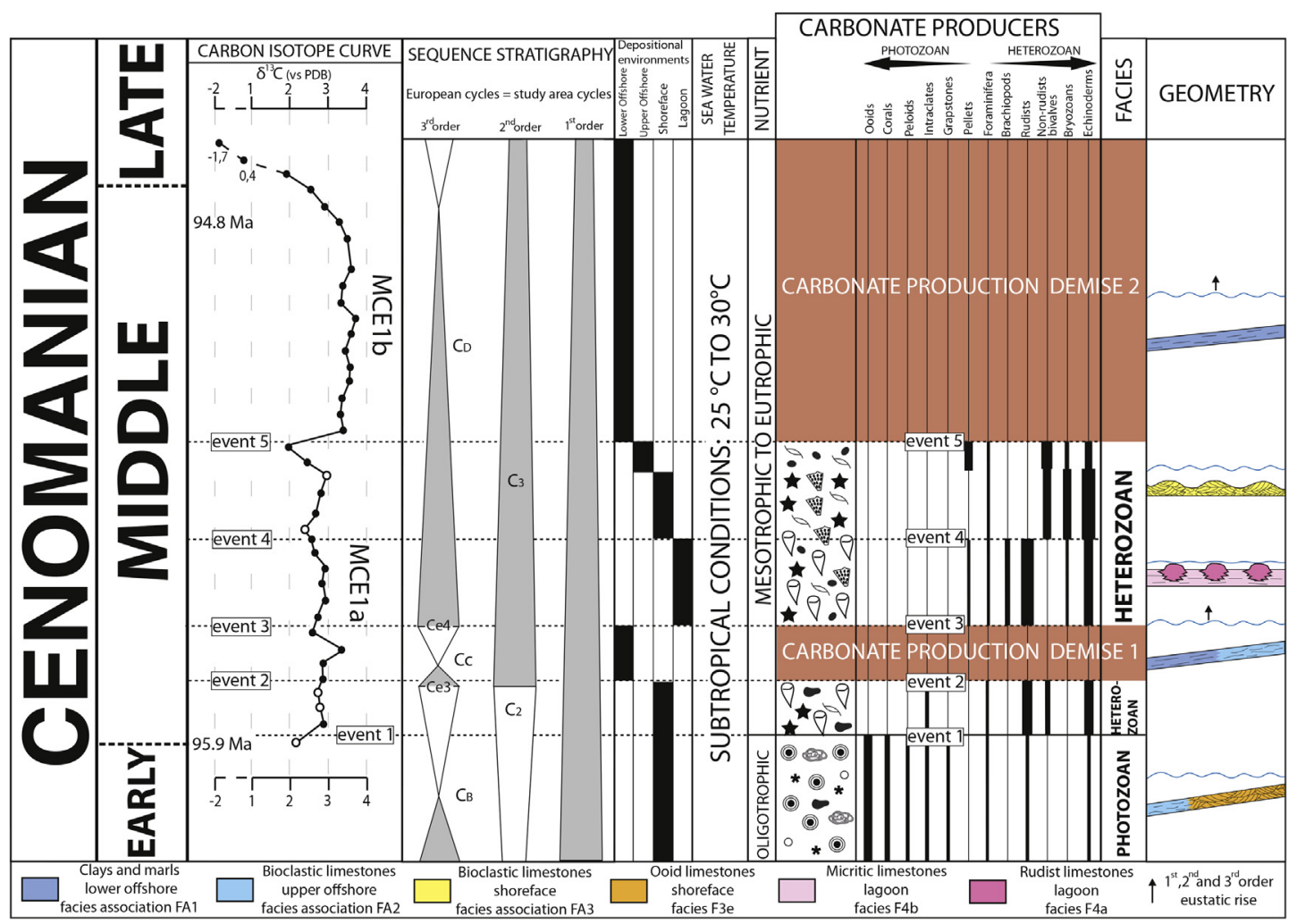

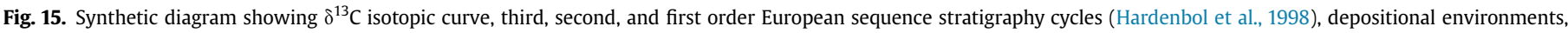

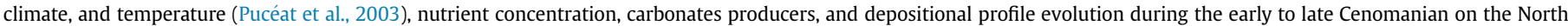
Aquitaine platform.

encrusting fossils like in major condensed surfaces. The ammonite and foraminifer biostratigraphic data display a relatively continuous recording for the middle Cenomanian series of the northern Aquitaine platform. The foraminifer species referenced by Moreau (1996) do not record any change at the $C_{B}-C_{C}$ boundary. These indications allow us to suppose that only a minor part of the $\delta^{13} \mathrm{C}$ signal could be missing in this interval. Eustatic control leading to decreasing water depth is assumed to be implicated in the development of the regionally-developed hardgrounds in northern Aquitaine and Sarthe (Francis, 1984). This hypothesis is supported by our study, which display a correlation between the top of a second-order regressive cycle in European basins and the $C_{B}-C_{C}$ sequence boundary.

Five major events corresponding to carbonate producers and facies turnovers and/or platform geometry changes mark the evolution of the Aquitaine carbonate platform during the Cenomanian (Fig. 15). During the transgressive systems tract and early regressive systems tract of the third-order sequence $C_{B}$, ooid to mud facies were deposited along a homoclinal ramp profile with no slope break. Event 1 occurred toward the end of the second-order regressive hemicycle $C_{2}$ and the third-order hemicycle $C_{B}$ (Fig. 15). It corresponds to the beginning of MCE1a, correlated with the development of rudist and echinoderm facies (heterozoan facies, Fig. 15). Event 2 corresponds to the start of the first carbonate production demise (carbonate production demise 1 ; sequence $C_{C}$, Figs. 5A, 12 and 15) characterized by the occurrence of clays and marls. Carbonate demise 1 is correlated with the highest $\delta^{13} \mathrm{C}$ value during the MCE1a excursion (3.3\%o, Fig. 15) and with the onset of the transgressive systems tract of the third-order sequence $C_{C}$ (Fig. 15). The accommodation/sedimentation ratio $(A / S)$ greater than 1 can be explained both by a global sea level rise as recorded on the European chart (Hardenbol et al., 1998) and by the carbonate production demise 1 (Figs. 5A, 12 and 15), which could favor the initiation of the transgressive systems tract of the third-order sequence $C_{C}$. The regressive systems tract of $C_{C}$ could have been controlled by sea level fall, as recorded on the eustatic chart (Hardenbol et al., 1998). After this first $\delta^{13} \mathrm{C}$ peak during MCE1a, the carbonate thrived again from event 3 to event 5 , through the early transgressive systems tract of the $C_{D}$ sequence (Figs. 11, 12 and 15). From event 3 to 4, heterozoan facies rich in rudists, echinoderms, and brachiopods developed within a flat lagoon with rudist bioherms (Figs. 11, 12 and 15). The transgressive systems tract of the $C_{D}$ sequence is correlated with a first, second, and third-order eustatic rise on the European eustatic chart (Hardenbol et al., 1998). Carbonate production was high due to rudist-rich facies (facies F4a and F4b) and accommodation was favored by a general sea-level rise at European scale and/or local subsidence. After deposition of the rudist facies (facies F4a and F4b), facies became more heterozoan from events 4 to 5 (facies F3a, F3b, F3c and F3d) with bryozoans, echinoderms, and non-rudist bivalves occurring in higher proportions (Fig. 15). Echinoderm-rich granular facies were deposited forming elongated $300 \mathrm{~m}$-wide and $10 \mathrm{~m}$-thick sand bars (Fig. 15). The mesotrophic to eutrophic conditions probably enhanced heterozoan producers at the origin of the sand bar carbonate facies. Event 5 (Fig. 15) occurred during the transgressive systems tract of the third-order sequence $C_{D}$ and was concomitant with a secondorder and first-order sea-level rise on the eustatic chart (Hardenbol et al., 1998). At the regional scale, event 5 showed a major facies change from shallow carbonates to clayey deposits (Moreau, 1996). This was the beginning of the MCE1b event, which was synchronous with the beginning of a second carbonate producer demise (carbonate production demise 2; Fig. 15). During this 
second $\delta^{13} \mathrm{C}$ excursion, marls and clays (facies association FA1) were deposited along a flat homoclinal ramp. No carbonate producers are observed, except very rare, small benthic foraminifera (Flabellammina, Daxia, Haplophragmoides, Ammobaculites) and planktonic foraminifera (Guembelitria, Hedbergella and Praeglobotruncana). Macrofauna are scarce and composed of rare Exogyra sp., nautilus and echinoids Hemiaster and Periaster (Moreau, 1996).

During the late early Cenomanian and the mid-Cenomanian on the north Aquitaine platform, different facies and geometries are observed when the $\delta^{13} \mathrm{C}$ values vary. When the $\delta^{13} \mathrm{C}$ ratio was below $2.5 \%$, photozoan facies dominated. Platform geometry corresponded to a ramp without slope breaks (Figs. 15 and 16). When $\delta^{13} \mathrm{C}$ values were between $2.5 \%$ and $3 \%$, the facies became heterozoan (Figs. 15 and 16), which could be explained by the appearance of mesotrophic conditions. Platform geometry was flat (shoal or lagoon) with high carbonate production leading to sandbars and rudist bioherms measuring several hundreds of meters. When the $\delta^{13} \mathrm{C}$ value exceeded $3 \%$, a carbonate production demise occurred (carbonate production demises 1 and 2, Figs. 15 and 16). Platform geometry was a clayey ramp with a very slight slope. The carbonate platform demise from the middle part of the mid-Cenomanian to the late Cenomanian was enhanced by a thirdorder sea level rise (Hardenbol et al., 1998), but may have been triggered by the occurrence of eutrophic conditions (Fig. 16).

\subsubsection{The Mid-Cenomanian Event: a possible scenario}

MCE1 was a positive $\delta^{13} \mathrm{C}$ excursion that was well expressed both in the marine domain (Jenkyns et al., 1994; Paul et al., 1994; Mitchell et al., 1996; Rodriguez-Lazaro et al., 1998; Stoll and Schrag, 2000; Jarvis et al., 2001, 2006; Gertsch et al., 2010; Wilmsen, 2007; Ando et al., 2009; Giraud et al., 2013; Reboulet et al., 2013) and terrestrial domain (Uramoto et al., 2007), indicating a global carbon atmospheric/marine reservoir change (Giraud et al.,
2013; Reboulet et al., 2013). MCE1 may reveal pumping of $\mathrm{CO}_{2}$ by incorporation of organic carbon $\left({ }^{12} \mathrm{C}\right)$ in marine sediments or biota, or in soils or terrestrial plants. MCE1 is marked by the local presence of organic-rich deposits in the tropical Atlantic Ocean (Demerara Rise; Friedrich et al., 2009) indicating possible organic burial in the deep Atlantic.

On the Aquitaine platform, the temporal concordance of both (1) the occurrence of mesotrophic to eutrophic conditions marked by carbonate producer turnover and (2) MCE1 (Fig. 15) suggests a connection between the global carbon cycle and shallow marine carbonates.

The Cenomanian is characterized by a first-order high sea level (Hardenbol et al., 1998). During the Cenomanian, the Aquitaine platform, which had been exposed since the late Jurassic, was flooded. High stand sea level intervals favored an increase in nutrient flux leading to eutrophic conditions in the marine domain. This process is a common explanation of positive $\delta^{13} \mathrm{C}$ excursions (Weissert and Mohr, 1996) and has been suggested by Reboulet et al. (2013) for MCE1. Heterozoan facies in shallow marine carbonates on the Aquitaine platform during the mid-Cenomanian suggest a similar scenario in which local carbon burial in marine and maybe terrestrial domains led to global carbon perturbation.

\section{Conclusion}

The limestone to clay deposits from late early Cenomanian to early late Cenomanian form 15 facies, deposited in lower and upper offshore, shoreface, lagoon, and backshore settings. Six distinct platform geometries occurred during the Cenomanian age: (1) an oolitic shallow ramp subject to detrital input; (2) a deeper ramp rich in echinoderms, pellets, and bivalves; (3) a platform with a large lagoon where rudist bioherms and foraminifera developed; (4) a platform dominated by granular facies with sand bars of several hundred meters rich in echinoderms, bivalves, and

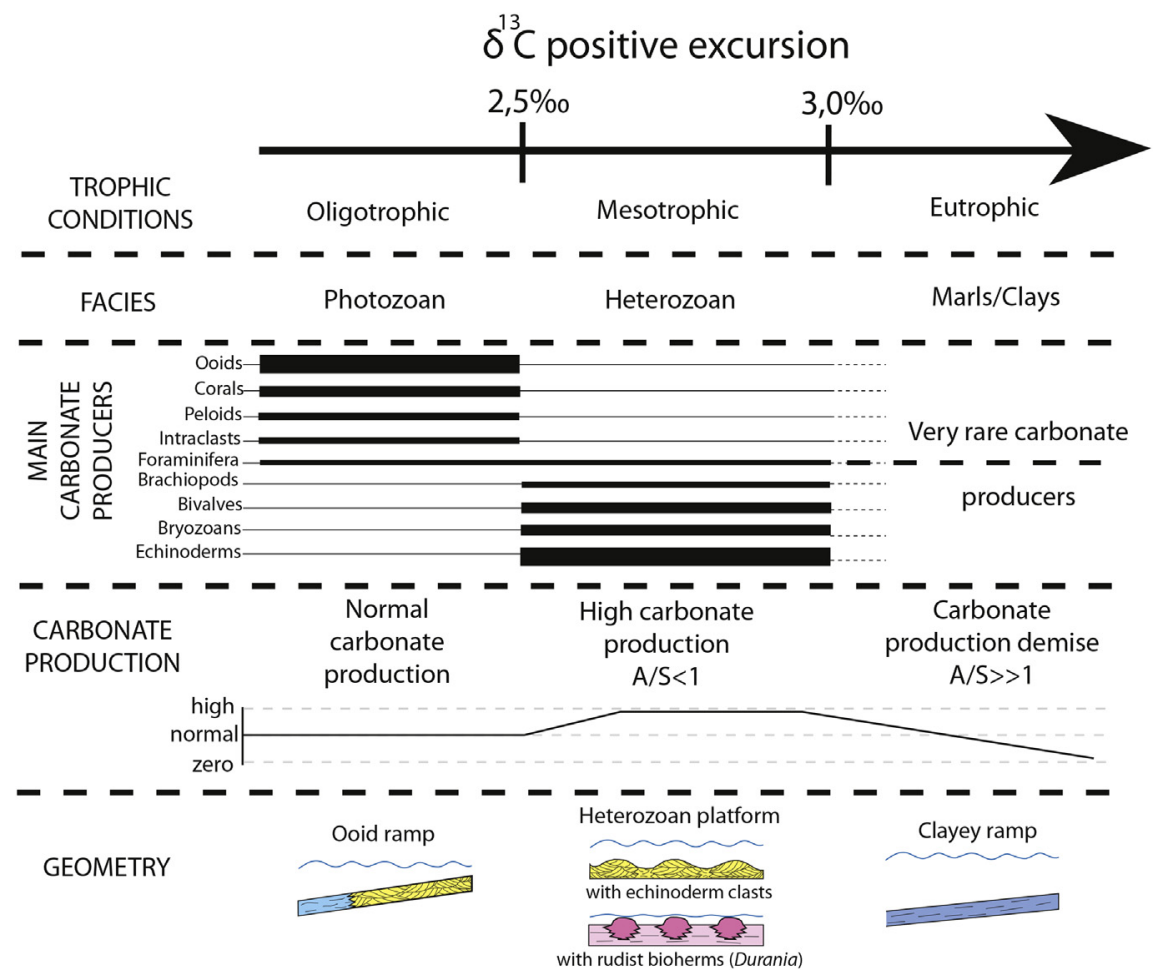

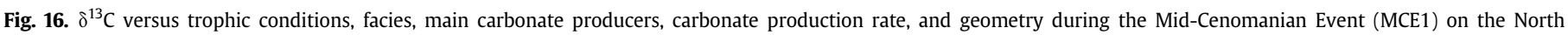
Aquitaine platform. 
bryozoans; (5) an upper offshore with echinoderms, bivalves, and pellets, and finally (6) marls and clayey sediments in a lower offshore setting. In terms of sequence stratigraphy, three thirdorder depositional sequences $\left(C_{B}, C_{C}, C_{D}\right)$ have been identified and are closely correlated with the European eustatic chart (Hardenbol et al., 1998). The Mid-Cenomanian Event (MCE1) is reported for the first time in a shallow marine environment, in the Aquitaine platform, showing two well-expressed positive excursions: MCE1a (amplitude of $+1.2 \%$ ) and MCE1b (amplitude of $+1.7 \%$ ). The analyses of diagenetic blocky calcite cements suggest that diagenetic processes did not affect the $\delta^{13} \mathrm{C}$ of micrite, which can be discussed in terms of the initial signal. MCE1 was synchronous with a turnover of carbonate producers resulting in the transition from photozoan facies during the early Cenomanian to heterozoan facies during the mid-Cenomanian. This change is indicative of the establishment of mesotrophic to eutrophic conditions from the early/mid-Cenomanian transition. Different geometries and facies are observed when $\delta^{13} \mathrm{C}$ varies. In the Aquitaine platform, for $\delta^{13} \mathrm{C}$ values below $2.5 \%$ the facies are photozoan, rich in ooids and coral fragments, and the depositional geometry corresponds to a homoclinal ramp profile with no slope break. For $\delta^{13} \mathrm{C}$ values between $2.5 \%$ and $3 \%$, the carbonate producers are heterozoan with the occurrence of echinoderms, bryozoans, and rudists and depositional geometry is a flat platform with high carbonate production (sandbars/rudist bioherms). When the $\delta^{13} \mathrm{C}$ value exceeded $3 \%$ on the Aquitaine platform, a carbonate demise occurred, which can be explained by both a eustatic rise and the establishment of eutrophic conditions. The coincidence of MCE1 with both (1) the occurrence of mesotrophic to eutrophic conditions marked by carbonate producer turnover and (2) the transgressive cycles, suggests that a eustatic sea-level rise leading to high trophic conditions could explain this positive $\delta^{13} \mathrm{C}$ excursion in the Atlantic and western Tethyan domain.

\section{Acknowledgments}

We thank Rocamat for financial support for this research program. We are grateful to Wilfrid Pilon, Dominique François, Guy Sardin, and Jean-Noël Bordron of Rocamat for their help and advice during core drilling of the Antenne and Picot boreholes and quarry sample collection. The authors thank the two anonymous reviewers and associate editor John W.M. Jagt for their constructive comments.

\section{References}

Amédro, F., Colleté, C., Fricot, C., Robaszynski, F., 1994. Extension inter-régionale de niveaux-repères dans les craies cénomaniennes du bassin anglo-parisien (Boulonnais, Aube, Kent). Bulletin d'Information des Géologues du Bassin de Paris 31, 3-8.

Amédro, F., Robaszynski, F., Colleté, C., Fricot, C., 1997. Les craies du CénomanienTuronien de l'Aube et du Boulonnais: des événements litho- et biosédimentaires communs. Annales de la Société Géologique du Nord 5, 189-197.

Ando, A., Huber, B.T., MacLeod, K.G., Ohta, T., Khim, B.-K., 2009. Blake Nose stable isotopic evidence against the mid-Cenomanian glaciation hypothesis. Geology $37,451-454$.

Biteau, J.-J., Le Marrec, A., Le Vot, M., Masset, J.-M., 2006. The Aquitaine Basin. Petroleum Geoscience 12, 247-273.

Bourgueil, B., Moreau, P., Vouvé, J., 1970. Notice explicative de la carte géologique d'Angoulême (1/50000). BRGM Editions, p. 20.

Brigaud, B., Durlet, C., Deconinck, J.F., Vincent, B., Pucéat, E., Thierry, J., Trouiller, A., 2009. Facies and climate/environmental changes recorded on a carbonate ramp: a sedimentological and geochemical approach on Middle Jurassic carbonates (Paris Basin, France). Sedimentary Geology 222, 181-206.

Coccioni, R., Galeotti, S., 2003. The mid-Cenomanian Event: prelude to OAE 2. Palaeogeography, Palaeoclimatology, Palaeoecology 190, 427-440.

Durlet, C., Loreau, J.-P., 1996. Séquence diagénétique intrinsèque des surfaces durcies : mise en évidence de surface d'émersion et de leur ablation marine. Exemple de la plate-forme bourguignonne, Bajocien (France). Compte rendus de l'Académie des sciences, Série 2, Sciences de la terre et des planètes 323 389-396.

El-Sabbagh, A., Aziz Tantawy, A., Keller, G., Khozyem, H., Spangenberg, J. Adatte, T., Gertsch, B., 2011. Stratigraphy of the Cenomanian-Turonian Oceanic Anoxic Event OAE2 in shallow shelf sequences of NE Egypt. Cretaceous Research 32, 705-722.

Embry, A.F., 2009. Practical Sequence Stratigraphy. Canadian Society of Petroleum Geologists, p. 79.

Floquet, M., 1998. Outcrop cycle stratigraphy of shallow ramp deposits: the Late Cretaceous Series on the Castillian ramp (northern Spain). In: Graciansky, P.C., Hardenbol, J., Jacquin, T., Vail, P.R. (Eds.), Mesozoic and Cenozoic Sequence Stratigraphy of European Basins, 60SEPM, Tulsa, pp. 343-361. Special Publication.

Föllmi, K.B., 2012. Early Cretaceous life, climate and anoxia. Cretaceous Research 35 , $230-257$.

Föllmi, K.B., Godet, A., Bodin, S., Linder, P. 2006. Interactions between environmental change and shallow water carbonate buildup along the northern Tethyan margin and their impact on the Early Cretaceous carbon isotope record. Paleoceanography 21, PA4211.

Forster, A., Schouten, S., Baas, M., Sinninghe Damsté, J.S., 2007. Mid-Cretaceous (Albian-Santonian) sea surface temperature record of the tropical Atlantic Ocean. Geology 35, 919-922.

Francis, I.H., 1984. Correlation between the North Temperate and tethyan Realms in the Cenomanian of Western France and the significance of Hardground Horizons. Cretaceous Research 5, 259-269.

Friedrich, O., Erbacher, J., Wilson, P.A., Moriya, K., Mutterlose, J., 2009. Paleoenvironmental changes across the Mid-Cenomanian Event in the tropical Atlantic Ocean (Demerara Rise, ODP Leg 207) inferred from benthic foraminiferal assemblages. Marine Micropaleontology 71, 28-40.

Frijia, G., Parente, M., Di Lucia, M., Mutti, M., 2015. Carbon and strontium isotope stratigraphy of the Upper Cretaceous (Cenomanian-Campanian) shallow-water carbonates of southern Italy: chronostratigraphic calibration of larger foraminifera biostratigraphy. Cretaceous Research 53, 110-139.

Gale, A.S., 1989. Field meeting at Folkestone Warren, 29th November, 1987. Proceedings of the Geologists' Association 100, 73-82.

Gale, A.S., 1990. A Milankovitch scale for Cenomanian time. Terra Nova 1, 420-425.

Gale, A.S., 1995. Cyclostratigraphy and correlation of the Cenomanian stage in Western Europe. In: House, M.R., Gale, A.S. (Eds.), Orbital Forcing Timescales and Cyclostratigraphy, Geological Society, London, Special Publication 85, pp. $177-197$.

Gale, A.S., Hancock, J.M., Kennedy, W.J., Petrizzo, M.R., Lees, J.A., Walaszczyk, I, Wray, D.S., 2008a. An integrated study (geochemistry, stable oxygen and carbon isotopes, nannofossils, planktonic foraminifera, inoceramid bivalves, ammonites and crinoids) of the Waxahachie Dam Spillway section, north Texas: a possible boundary stratotype for the base of the Campanian Stage. Cretaceous Research 29, 131-167.

Gale, A.S., Voigt, S., Sageman, B.B., Kennedy, W.J., 2008b. Eustatic sea-level record for the Cenomanian (Late Cretaceous) extension to the Western Interior Basin, USA. Geology 36, 859-862.

Gertsch, B., Keller, G., Adatte, T., Berner, Z., Kassab, A.S., Tantawy, A.A.A., ElSabbagh, A.M., Stueben, D., 2008. Cenomanian-Turonian transition in a shallow water sequence of the Sinai, Egypt. International Journal of Earth Sciences 99 165-182.

Gertsch, B., Adatte, T., Keller, G., Tantawy, A.A.M., Berner, Z., Mort, H.P. Fleitmann, D., 2010. Middle and late Cenomanian oceanic anoxic events in shallow and deeper shelf environments of western Morocco. Sedimentology 57, 1430-1462.

Giraud, F., Reboulet, S., Deconinck, J.F., Martinez, M., Carpentier, A., Bréziat, C., 2013. The Mid-Cenomanian Event in southeastern France: evidence from palaeontological and clay mineralogical data. Cretaceous Research 46, 43-58.

Gradstein, F.M., Ogg, J.G., Smith, A.G., Agterberg, F.P., Bleeker, W., Cooper, R.A., Davydov, V., Gibbard, P., Hinnov, L.A., House, M.R., Lourens, L., Luterbacher, H.-P., McArthur, J., Melchin, M.J., Robb, L.J., Sadler, P.M., Shergold, J., Villeneuve, M. Wardlaw, B.R., Ali, J., Brinkhuis, H., Hilgen, F.J., Hooker, J., Howarth, R.J. Knoll, A.H., Laskar, J., Monechi, S., Powell, J., Plumb, K.A., Raffi, I., Röhl, U., Sanfilippo, A., Schmitz, B., Shackleton, N.J., Shields, G.A., Strauss, H., Van Dam, J. Veizer, J., Van Kolfschoten, T., Wilson, D., 2004. Geologic Time Scale 2004. Cambridge University Press, p. 589.

Gustafsson, M., Holbourn, A., Kuhnt, W., 2003. Changes in Northeast Atlantic temperature and carbon flux during the Cenomanian/Turonian paleoceanographic event: the Goban Spur stable isotope record. Palaeogeography, Palaeoclimatology, Palaeoecology 201, 51-66.

Haq, B.U., 2014. Cretaceous eustasy revisited. Global and Planetary Change 113, 44-58.

Haq, B.U., Hardenbol, J., Vail, P.R., 1987. Chronology of fluctuating sea levels since the Triassic Science 235, 1156-1167.

Hardas, P., Mutterlose, J., Friedrich, O., Erbacher, J., 2012. The Middle Cenomanian Event in the equatorial Atlantic: the calcareous nannofossil and benthic foraminiferal response. Marine Micropaleontology 96-97, 66-74.

Hardenbol, J., Thierry, J., Farley, M.B., Jacquin, T., De Graciansky, P.-C., Vail, P.R., 1998 Cretaceous sequence chronostratigraphy. In: De Graciansky, P.-C., Hardenbol, J., Jacquin, T., Vail, P.R. (Eds.), Mesozoic and Cenozoic Sequence Stratigraphy of European Basins, SEPM Special Publication 60, p. 786

Huber, B.T., Norris, R.D., MacLeod, K.G., 2002. Deep-sea paleotemperature record of extreme warmth during the Cretaceous. Geology 30, 123-126. 
James, N.P., 1997. The cool-water carbonate depositional realm. In: James, N.P. Clarke, J.A.D. (Eds.), Cool-water Carbonates, SEPM Special Publblication 56, p. 20.

Jarvis, I., Gale, A.S., Jenkyns, H.C., Pearce, M.A., 2006. Secular variation in Late Cretaceous carbon isotopes: a new $\delta 13 \mathrm{C}$ carbonate reference curve for the Cenomanian-Campanian (99.6-70.6 Ma). Geological Magazine 143, 561-608.

Jarvis, I., Murphy, A.M., Gale, A.S., 2001. Geochemistry of pelagic and hemipelagic carbonates: criteria for identifying systems tracts and sea-level changes. Journal of the Geological Society, London 158, 685-696.

Jenkyns, H.C., Gale, A.S., Corfield, R.M., 1994. Carbon- and oxygen-isotope stratigraphy of the English Chalk and Italian Scaglia and its palaeoclimatic significance. Geological Magazine 131, 1-34.

Juignet, P., Louail, J., Neumann, M., Pourmotamed, F., 1974. Pénétration de Foraminifères mésogéens dans le sud-ouest du Bassin de Paris au Cénomanien. Compte rendu des séances de l'Académie des Sciences de Paris, Série D, Sciences Naturelles 278, 2279-2282.

Kim, S.-T., O'Neil, J.R., 1997. Equilibrium and nonequilibrium oxygen isotope effects in synthetic carbonates. Geochimica et Cosmochimica Acta 61, 3461-3475.

Kuhnt, W., Holbourne, A., Gale, A.S., El Hassane, C., 2009. Cenomanian cyclostratigraphy and sea level fluctuations in the Tarfaya Basin (S-W Morocco) Bulletin of the Geological Society of America 121, 1695-1710.

Lasseur, E., Néraudeau, D., Guillocheau, F., Robin, C., Hanot, F., Videt, B., Mavrieux, M., 2008. Stratigraphie et sédimentologie comparées du Crétacé Supérieur du Bassin de Paris et du Bassin Nord-Aquitain. Excursion du Groupe Français du Crétacé, p. 100.

Lavastre, V., Ader, M., Buschaert, S., Petit, E., Javoy, M., 2011. Water circulation control on carbonate- $\delta^{18} \mathrm{O}$ records in a low permeability clay formation and surrounding limestones: the Upper Dogger-Oxfordian sequence from the eastern Paris basin, France. Applied Geochemistry 26, 818-827.

Meunier, A., Proust, D., Moreau, P., 1999. Geological significance of two smectiterich beds from Lower Cenomanian sediments, northern Aquitaine basin, France. Bulletin de la Société géologique de France 170, 873-882.

Miller, K.G., Kominz, M.A., Browning, J.V., Wright, J.D., Mountain, G.S., Katz, M.E. Sugarman, P.J., Cramer, B.S., Christie-Blick, N., Pekar, S.F., 2005. The Phanerozoic record of global sea-level change. Science 310, 1293-1298.

Mitchell, S.F., Paul, C.R.C., Gal, A.S., 1996. Carbon isotopes and sequence stratigraphy. In: Howell, J.A., Aitken, J.F. (Eds.), High Resolution Sequence Stratigraphy: Innovations and Applications, Geological Society, London, Special Publication 104, pp. $11-24$.

Mitchell, S.F., Carr, I.T., 1998. Foraminiferal response to mid-Cenomanian (Upper Cretaceous) palaeoceanographic events in the Anglo-Paris Basin (Northwest Europe). Palaeogeography, Palaeoclimatology, Palaeoecology 137, 103-125.

Moreau, P., 1977. Les environnements sédimentaires marins dans le Cénomanien du nord du Bassin de l'Aquitaine. Bulletin de la Société géologique de France 19 $281-288$.

Moreau, P., 1993. La transgression cénomanienne sur la marge septentrionale du bassin de l'aquitaine (Charentes). Thèse d'Etat. In: Flanc Nord du synclinal de Saintes et de l'Angoumois. Modalité d'une invasion marine. Vol. I, II, III. Université de Poitiers.

Moreau, P., 1996. Analyse de la transgression cénomanienne sur la bordure Nordoccidentale du Bassin de l'Aquitaine. Géologie de la France 1, 3-16.

Moreau, P., Francis, H.I., Kennedy, W.J., 1983. Cenomanian Ammonites from Northern Aquitaine. Cretaceous Research 4, 317-339.

Moreau, P., Neumann, M., Troncetti, G., 1978. Les principaux Foraminifères benthiques du Cénomanien de Charente-Maritime et de Provence: répartition comparée. Géologie Méditerranéenne 5, 137-146.

Moreau, P., Platel, J.-P., 1982. L'Evolution Paléogéographique de la Plate-forme Nordaquitaine durant le Crétacé supérieur. Cretaceous Research 3, 47-55.

Mutti, M., Hallock, P., 2003. Carbonate systems along nutrient and temperature gradients: some sedimentological and geochimical constraints. International Journal of Earth Sciences 92, 465-475.

Paul, C.R.C., Mitchell, S.F., Marshall, J.D., Leary, P.N., Gale, A.S., Duane, A.M., Ditchfield, P.W. 1994. Palaeoceanographic events in the Middle Cenomanian of Northwest Europe. Cretaceous Research 15, 707-738.
Pellenard, P., Tramoy, R., Pucéat, E., Huret, E., Martinez, M., Bruneau, L., Thierry, J., 2014. Carbon cycle and sea-water palaeotemperature evolution at the MiddleLate Jurassic transition, eastern Paris Basin (France). Marine and Petroleum Geology 53, 30-43.

Philip, J., Floquet, M., Platel, J.P., Bergerat, F., Sandulescu, M., Bara-Boshkin, E., Amon, E., Guiraud, R., Valset, D., Le Nindre, Y., Ziegler, M., Poisson, A., Bouaziz, S., 2000. Atlas Peri-Tethys, Palaeogeographical map 14-Late Cenomanian (94.7 to 93.5 Ma). CCGM/CGMW, Paris.

Platel, J.-P., 1987. Le Crétacé supérieur de la plate-forme septentrionale du Bassin d'Aquitaine. Stratigraphie et évolution géodynamique. BRGM Editions, Orléans (Thèse d'Etat, Université de Bordeaux).

Platel, J.-P., 1996. Stratigraphie, sédimentologie et évolution géodynamique de la plate-forme carbonatée du Crétacé supérieur du nord du bassin d'Aquitaine. Géologie de la France 1, 33-58.

Platel, J.-P., 1998. The Turonian rudist-bearing carbonate platforms of the Charentes and Perigord areas, Aquitaine basin (France). Geobios 22, 295-311.

Pomar, L., Gili, E., Obrador, A., Ward, W.C., 2005. Facies architecture and highresolution sequence stratigraphy of an Upper Cretaceous platform margin succession, southern central Pyrenees, Spain. Sedimentary Geology 175, 339-365.

Pucéat, E., Lécuyer, C., Sheppard, S.M.F., Dromart, G., Reboulet, S., Grandjean, P., 2003. Thermal evolution of Cretaceous Tethyan marine waters inferred from oxygen isotope composition of fish tooth enamels. Paleoceanography $18,7-1 /$ 7-12.

Pucéat, E., Lécuyer, C., Donnadieu, Y., Naveau, P., Cappetta, H., Ramstein, G., Huber, B.T., Kriwet, J., 2007. Fish tooth $\delta^{18} \mathrm{O}$ revising Late Cretaceous meridional upper ocean water temperature gradients. Geology 35, 107-110.

Purser, B.H., 1969. Syn-sedimentary marine lithification of middle Jurassic limestones in the Paris Basin. Sedimentology 12, 205-230.

Reboulet, S., Giraud, F., Colombié, C., Carpentier, A., 2013. Integrated stratigraphy of the Lower and Middle Cenomanian in a Tethyan section (Blieux, southeast France) and correlations with Boreal basins. Cretaceous Research 40, 170-189.

Robaszynski, F., Juignet, P., Gale, A.S., Amédro, F., Hardenbol, J., 1998. Sequence stratigraphy in the Cretaceous of the Anglo-Paris Basin, exemplified by the Cenomanian stage. In: de Graciansky, P.C., Hardenbol, J., Jacquin, T., Vail, P.R. (Eds.), Mesozoic and Cenozoic Sequence Stratigraphy of European Basins, SEPM (Society for Sedimentary Geology), Special Publication 60, pp. 363-386.

Rodriguez-Lazaro, J., Pascual, A., Elorza, J., 1998. Cenomanian events in the deep western Basque Basin: the Leioa section. Cretaceous Research 19, 673-700.

Schlager, W., 2004. Fractal nature of stratigraphic sequences. Geology 32, 185-188.

Smith, A.B., Monks, N.E.A., Gale, A.S., 2006. Echinoid distribution and sequence stratigraphy in the Cenomanian (Upper Cretaceous) of southern England. Proceedings of the Geologists' Association 117, 207-217.

Stoll, H.M., Schrag, D.P., 2000. High-resolution stable isotope records from the Upper Cretaceous rocks of Italy and Spain: glacial episodes in a greenhouse planet? Geological Society of America, Bulletin 112, 308-319.

Swart, P., Eberli, G., 2006. The nature of the $\delta^{13} \mathrm{C}$ of periplatform sediments: implications for stratigraphy and the global carbon cycle. Sedimentary Geology $175,115-129$.

Uramoto, G.-I., Fujita, T., Takahashi, A., Hirano, H., 2007. Cenomanian (Upper Cretaceous) carbon isotope stratigraphy of terrestrial organic matter for the Yezo Group, Hokkaido, Japan. Island Arc 16, 465-478.

Van Wagoner, J.C., Posamentier, H.W., Mitchum, R.M., Vail, P.R., Sarg, J.F., Loutit, T.S., Hardenbol, J., 1988. An overview of the fundamentals of sequence stratigraphy and key definitions. In: Wilgus, C., Hastings, B.S., Kendall, C.G., Posamentier, H.W., Ross, C.A., Van Wagoner, J.C. (Eds.), Sea Level Changes: an Integrated Approach, SEPM Special Publication 42, pp. 39-46.

Weissert, H., Mohr, H., 1996. Late Jurassic climate and its impact on carbon cycle. Palaeogeography, Palaeoclimatology, Palaeoecology 122, 27-43.

Wilmsen, M., 2007. Integrated stratigraphy of the upper Lower - lower Middle Cenomanian of northern Germany and southern England. Acta Geologica Polonica 57, 263-279. 